\title{
A MAPPING OF OXIDATIVE ENZYMES IN THE HUMAN BRAIN*
}

\author{
Reinhard L. Friede and LaDona M. Fleming \\ Mental Health Research Institute \\ University of Michigan, Ann Arbor, Michigan
}

(Received 2 October 1961)

THIS ARTICLE provides a quantitative mapping of the distribution of DPN-diaphorase activity in the nuclei and regions of the human brain. Measurements in fibre tracts were included although the article refers mainly to findings in grey matter; a detailed account of the enzyme pattern in white matter was published previously (FRIEDE, 1961b).

\section{MATERIAL AND METHODS}

Histochemical techniques. Six normal adult human brains from average post mortem material were used. They were placed in neutral $10 \%$ formalin $3-9 \mathrm{hr}$ after death and fixed at $5^{\circ}$ for 2 days. After 1-day fixation, the material was blocked into pieces $4-6 \mathrm{~mm}$ thick. Frozen sections were cut at $30 \mu$, rinsed in $\mathrm{H}_{2} \mathrm{O}$ and incubated for $2 \mathrm{hr}$ at $38^{\circ}$ with frequent agitation. The method of FARBER, SternberG and DuNi.AP (1956) was employed, using Nitro BT and tris buffer. Other techniques such as that of SCARPELLI, Hess and PEARSE (1958) and other tetrazolium salts had been used with identical results. $\dagger$ The $\mathrm{pH}$ of the incubation medium was always adjusted to 7-35. Sections from each block were incubated in individual jars and the proportion of incubation media to tissue was approximately the same for each. The reaction was stopped by transferring the sections to $10 \%$ neutral formalin. Half of the sections were mounted in glycerin gel; the others were dehydrated and mounted in Permount. Random material was used for the demonstration of succinic dehydrogenase (NACHLASS et al., 1957) and cytochrome oxidase (BuRsrone, 1958) in $60 \mu$ unfixed sections.

Quantitative sechniques. For quantitative DPN-diaphorase determinations large series were used from three normal human brains. They were fixed and sectioned in the same way as sections used for histochemical studies. The incubation medium was the same except that the monotetrazolium salt INT was substituted for Nitro BT because Nitro BT formazan is very insoluble. The final concentration of tetrazolium salt in the incubation medium was $0.23 \mathrm{mg} / \mathrm{ml}$ for both the histochemical and quantitative studies. The sections were stored in chilled distilled $\mathrm{H}_{2} \mathrm{O}$ until all the sections from one brain were cut. After all the sections were transferred to a beaker containing the buffer component of the incubation medium, they were gently poured into the rest of the incubation medium in a 21 . Erlenmeyer flask which was shaken constantly in an Eberbach shaker-water bath at $38^{\circ}$ for 2 hr. The reaction was stopped by transferring the entire contents of the flask into a large quantity of $10 \%$ formalin. The constant shaking increased the rate of the reaction and prevented uneven staining due to folded tissue. To make an accurate comparison of the amount of INT reduced formazan in all areas it was necessary completely to eliminate even minute variations in the time and temperature of fixation and incubation, in the degree of shaking and, particularly, in the proportion of tissue to incubation medium. Thus, all the sections from one brain were incubated in a single large quantity $(600 \mathrm{ml})$ of incubation medium. When this is done, it is a reliable method for showing patterns within one specimen. It has been shown that the quantity of formazan formed is directly proportional to the enzyme activity (SHELTON and RICE, 1957). If the method was to be applied to experimental specimens, it was necessary to incubate sections from a control specimen in the same incubation bath each time. A $3 \times 2$ in. slide was covered with parafilm and each section was temporarily mounted on this to facilitate punching of small discs in the areas of interest. Sharpened stainless steel tubes, $1.1 \mathrm{~mm}$ and $2.4 \mathrm{~mm}$ in diameter were used to cut the discs. The INT formazan of each disc was extracted in $3 \mathrm{ml}$ of $3: 1(\mathrm{v} / \mathrm{v})$ ethanol-tetrachloroethylene (Eastman, Rochester, N.Y.). One drop of $1 \mathrm{~N}-\mathrm{HCl}$ was added to each tube of extracted formazan, to ensure that the colour would be stable for

* This investigation was supported by U.S. Public Health Grant B3250.

$\dagger$ The reliabilityof these methods in formalin-fixed tissuc has been tested extensively by comparison with assays in tissue homogenates; this data will be reported later. 
several hours. The colour density was read at $500 \mathrm{~m} \mu$ in a Beckman DU spectrophotometer and compared with standards prepared by dissolving weighed amounts of INT formazan (Synthetical Laboratories, Niles) in 3:1 ethanol tetrachlorethylene. The absorption curve of both the commercial INT formazan and that produced in the sections had a peak at $500 \mathrm{~m} \mu$. Controls without substrate were run for each area. The mean values obtained for all areas consistently ranged from $2 \cdot 0$ to $2.4 \mu \mathrm{g}$ formazan. This was considered negligible and was not reported with the data. Control discs of a specific area from two $15 \mu$ sections gave the same result as one disc from a $30 \mu$ section. Thus, the results were independent of section thickness up to $30 \mu$.

The discs of the olivary and dentate nuclei were photographed before the formazan was extracted from them. The photomicrographs were measured planimetrically to determine the proportion of grey and white matter in each. By using this ratio and known values from adjacent discs of white matter, the formazan per $0.0434 \mathrm{~mm}^{3}$ was calculated for these nuclei.

\section{RESULTS}

Arrangement of data. Table 1 contains the results of about 2,400 measurements made in three human brains. Since the data for a given nucleus were in the same order in all the brains, the means refer to the collected data from all three brains; the number of measurements for any given nucleus was about the same in each brain. This pooling of data increased the standard deviation slightly but it provided an average, typical pattern of enzyme gradations among nuclei. Measurements in the nucleus anterior dorsalis thalami and the nucleus mammilaris were listed separately for case No. 2 because the data in these areas differed from those of cases Nos. 1 and 3.

Data previously obtained in a mapping of the cat brain (FRIEDE, 1961c) are included in Table 1 to facilitate comparison; they refer to densitometric measurements of the succinic dehydrogenase reaction in tissue sections and to counts of the capillarization of nuclei in the medulla oblongata of the cat; for further information, the histochemical atlas should be consulted.

The typical cytological details of enzyme distribution in the nuclei of the human brain are described in Table 2. Particular attention is focussed on the gradations of enzymic activity in the perikarya and the neuropil, and on the sharpness of the borders

Table 1. Distribution of DPN-diaphorase IN THE BRAIN

\begin{tabular}{|c|c|c|c|}
\hline \multirow{2}{*}{\multicolumn{2}{|c|}{$\begin{array}{c}\text { Human brain } \\
\text { Distribution } \\
\text { of DPN-diaphorase }\end{array}$}} & \multicolumn{2}{|c|}{ Cat brain } \\
\hline & & \multirow{2}{*}{$\begin{array}{c}\text { Succinic } \\
\text { dehydrogenase } \\
\text { Densitometric } \\
\text { extinction } \\
\text { units }\end{array}$} & \multirow{2}{*}{$\begin{array}{c}\text { Capillarization } \\
\begin{array}{c}x / 22.5 \mathrm{~mm} \\
\text { capillarics } / \mathrm{mm}^{3} \\
\text { lissue }\end{array}\end{array}$} \\
\hline Nucleus* & $\begin{array}{c}\text { /g Forma- } \\
\text { zan } / 0.0434 \mathrm{~mm}^{3} \\
\text { tissue }\end{array}$ & & \\
\hline \multicolumn{4}{|c|}{ Medulla spinalis (cervical) } \\
\hline Columna ventralis & $33 \because .4$ & & \\
\hline Columna lateralis & $35 \div 5$ & & \\
\hline Dorsomedial cell groups & $30 \cdot 5=3$ & & \\
\hline Nucl. tractus spinalis trigemini & $38 \cdot 2+6$ & & \\
\hline Nucl. gracilis (caudal part) & $22 \cdot 5 \div 3$ & & \\
\hline $\begin{array}{l}\text { Tissue surrounding the canalis } \\
\text { centralis }\end{array}$ & $24 \cdot 5=3$ & & \\
\hline Ventral tracts & $15 \cdot 0 \div 3$ & & \\
\hline Lateral tracts & $16 \cdot 0 \pm 2$ & & \\
\hline Dorsal tracts & $12 \cdot 0 \div 1$ & & \\
\hline
\end{tabular}

* Anatomical names according to Olszewski and Baxtra (1954). 
TABLE 1 (cont'd)

\begin{tabular}{|c|c|c|c|}
\hline \multirow{2}{*}{\multicolumn{2}{|c|}{$\begin{array}{l}\text { Human brain } \\
\text { Distribution } \\
\text { of DPN-diaphorase }\end{array}$}} & \multicolumn{2}{|c|}{ Cat brain } \\
\hline & & \multirow{2}{*}{$\begin{array}{c}\begin{array}{c}\text { Succinic } \\
\text { dehydrogenase }\end{array} \\
\text { Densitometric } \\
\text { extinction } \\
\text { units }\end{array}$} & \multirow{2}{*}{$\frac{\text { Capillarization }}{\begin{array}{c}x / 22.5 \mathrm{~mm} \\
\text { capillaries } / \mathrm{mm}^{3} \\
\text { tissue }\end{array}}$} \\
\hline Nucleus $\dagger$ & $\begin{array}{c}\mu \mathrm{g} \text { Forma- } \\
\text { zan } / 0 \cdot 0434 \mathrm{~mm}^{3} \\
\text { tissue }\end{array}$ & & \\
\hline \multicolumn{4}{|c|}{ Mcdulla oblongata } \\
\hline $\begin{array}{l}\text { Nucl. gracilis } \\
\text { Nucl. cuneatus medialis }\end{array}$ & $\begin{array}{l}30=4 \\
29=4\end{array}$ & 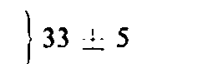 & $32 \pm 2$ \\
\hline Nucl. cuneatus lateralis & $44+5$ & $43 \therefore 7$ & $46+4$ \\
\hline Nucl. tractus desc. $n$. trigem & $31+8$ & & \\
\hline (b) confined nucleus & 395 & $34 \pm 3$ & $32+3$ \\
\hline Nucl. n. hypoglossi & $43 \pm 5$ & $46: 5$ & $49 \pm 5$ \\
\hline Nucl. tractus solitarii & $28 \therefore 4$ & $16=3$ & $26 \pm 3$ \\
\hline Nucl. reticularis & $30 \pm 5$ & 29.14 & $\left\{\begin{array}{l}29 \\
20\end{array}\right.$ \\
\hline Nucl. reticularis lateralis & $34 \ldots 6$ & $41 \pm 8^{*}$ & $\begin{array}{l}32 \pm 2 \\
41 \pm 2\end{array}$ \\
\hline Nucl. olivaris & $57+9$ & $53 \div 7$ & $52 \pm 10$ \\
\hline Nucl. vestibularis medialis & $43 \pm 4$ & $45 \pm 5$ & $44 \pm 3$ \\
\hline Nucl. vestibularis lateralis & $33:=4$ & $25=4$ & $35 \pm 3$ \\
\hline Tuberculum acousticum & $47-6$ & $37 \therefore 6$ & $52 \div 3$ \\
\hline Nucl. prepositus hypoglossi & $37 \doteq 8$ & $35 \div 4$ & $35 \pm 3$ \\
\hline Nucl. cochlearis & & $36 \because 6$ & $43 \cdot+3$ \\
\hline Nucl. arcuatus & $51 \div 6$ & & \\
\hline Nucl. centralis medialis & $42 \pm 4$ & & \\
\hline Tractus pyramidalis & 132 & $8 \approx 2$ & $16 \pm 2$ \\
\hline Corpus restiforme & $14 \pm 2$ & & \\
\hline \multicolumn{4}{|c|}{ Cerebellum } \\
\hline Stratum moleculare & $33 \therefore 5$ & & \\
\hline Stratum granulare & $32 \pm 7$ & & \\
\hline Cortex (total) & $34 \div 7$ & & \\
\hline Nucl. fastigii & $46 \pm 1$ & & \\
\hline Nucl. dentatus & $55+8$ & & \\
\hline Substantia alba & $17 \div 2$ & & \\
\hline \multicolumn{4}{|c|}{ Pons } \\
\hline Nucl. reticularis & $25: 4$ & $38 \cdot 5^{*}$ & $32 \div 2$ \\
\hline Nucl. $n$. abducentis & 345 & & \\
\hline Griseum centrale & $23 \div 7$ & $33=5$ & $31 \pm 5$ \\
\hline Nucl. supragenualis & $22 \div 5$ & & \\
\hline Nucl. coeruleus & $19=1$ & $21 \pm 5$ & $28 \pm 2$ \\
\hline Nucl. vestibularis superior & $26=3$ & $32 \pm 5^{*}$ & $34 \pm 6$ \\
\hline \multicolumn{4}{|l|}{ Nucl. vestibularis lateralis } \\
\hline pars dorsalis & $34 \pm 5$ & & \\
\hline Nucl. n. trigemini motorius & $39=9$ & & \\
\hline Nucl. n. trigemini sensibilis & 31.11 & & \\
\hline Nucl. parabrachialis & $22 \div 3$ & & \\
\hline \multirow{2}{*}{$\begin{array}{l}\text { Nucl. parolivaris and nucl. } \\
\text { olivaris superior } \\
\text { Nucl. reticularis Bechterew } \\
\text { (rcticular part) }\end{array}$} & $42 \pm 7$ & $\left\{\begin{array}{l}59 \pm 6^{*} \\
59 \pm 2^{*}\end{array}\right.$ & $\left\{\begin{array}{l}56 \pm 3 \\
53 \pm 3\end{array}\right.$ \\
\hline & $38+3$ & & \\
\hline
\end{tabular}

* Slightly higher densiometric data are marked by asterisk wherever it is felt that the spectrophotometric data include adjacent tissue with a weaker reaction.

† Anatomical names according to OLszewsKI and BAXTER (1954). 
TABIE 1 (cont'd)

\begin{tabular}{|c|c|c|c|}
\hline \multirow{2}{*}{\multicolumn{2}{|c|}{$\begin{array}{c}\text { Human brain } \\
\text { Distribution } \\
\text { of DPN-diaphorase }\end{array}$}} & \multicolumn{2}{|c|}{ Cat brain } \\
\hline & & $\begin{array}{c}\text { Succinic } \\
\text { dehydrogenase }\end{array}$ & Capillarization \\
\hline Nucleus & $\begin{array}{c}\mu \mathrm{g} \text { Forma- } \\
\text { zan } / 0 \cdot 0434 \mathrm{~mm}^{3} \\
\text { tissue }\end{array}$ & $\begin{array}{l}\text { Densitometric } \\
\text { extinction } \\
\text { units }\end{array}$ & $\begin{array}{c}\mathrm{x} / 22.5 \mathrm{~mm} \\
\text { capillaries } / \mathrm{mm}^{3} \\
\text { tissue }\end{array}$ \\
\hline
\end{tabular}

Nucl. reticularis Bechterew

(compact parts)

Nucl. pontis (reticular part)

Nucl. pontis (compact part)

Pyramidal tract

Brachia pontis

Brachium conjunctivum

Colliculus posterior (caudal part)

Colliculus posterior (cranial part)

Intercollicular region

Griseum centrale (dorsal portion)

Griseum centrale (ventral portion)

Area cuneiforme

Nucl. trochlearis

Nucl. parabrachialis

Lemniscus lateralis

Tractus pyramidalis

Colliculus superior (lamina superficialis)

Colliculus superior (laminae profundae)

Regio S

Griseum centrale (dorsolateral portion)

Griscum centralc

(ventromedial portion)

Dorsal crest (Nucl. dorsalis)

Pretectal area

Nucl. n. oculomotorii

Nucl. ruber (pars magnocellularis)

Nucl. ruber

$$
\text { (transitional part) }
$$

Nucl. ruber (pars parvocellularis)

Nucl. niger

Pedunculi cerebri
Pons (cont.)
$48 \div 5$
$38 \div 2$
$47 \div 3$
$14 \therefore 3$
$13=2$
$14 \div 2$

$\begin{array}{rlr}45 \therefore 8 & 48 \pm 4 \\ 41: 10 & 46 \div 5 \\ 8:: 2 & 16 \pm 2\end{array}$

Midbrain (colliculus inferior)

$\begin{array}{lll}51: 3 & 66: 8^{*} & 51 \pm 3 \\ 37 \therefore 3 & & \\ 30 \pm 3 & & \\ 32 \therefore 3 & 26 \therefore 4 & 26 \pm 3 \\ 17: 2 & 19: 3 & 20 \div 2 \\ 23 \div 2 & 20 \pm 4 & 26 \pm 2 \\ 43=2 & 58 \pm 7^{*} & 43 \pm 4 \\ 25 \div 4 & 30: 6 & 28 \div 3 \\ 11: 2 & 8 \pm 2 & 16 \pm 2 \\ 15=3 & 852 & \end{array}$

Midbrain (colliculus superior)
$43 \cdot 3$
$64:-11^{*}$
$50 \div \div 9$
$35 \div 4$
$36 \div 1$
$33 \div 2$
$31 \quad \therefore 4$
$42 \therefore 5$
29 - 3
$32 \div 6$
(2)
$27=4$
$23 \div 2$
$30 \div 3$
$51 \div 2$
$58 \div 7^{*}$
$43 \div 4$
$25: 3$
$31 \therefore 3$
$42 \div 7$
$26=2$
$43 \div 5$
$19=3$
$8 \div 2$
$38+3$
$30 \pm 2$
$16 \pm 2$

* Slightly higher densiometric data are marked by asterisk wherever it is felt that the spectrophotometric data include adjacent tissue with a weaker reaction.

$\dagger$ Anatomical names according to OI.SzEWSKI and BAXreR (1954). 
TABLE $1\left(\operatorname{cont}^{\circ} d\right)$

\begin{tabular}{|c|c|c|c|}
\hline \multicolumn{2}{|c|}{$\begin{array}{c}\text { Human brain } \\
\text { Distribution } \\
\text { of DPN-diaphorase }\end{array}$} & \multicolumn{2}{|c|}{$\begin{array}{l}\text { Human brain } \\
\text { Distribution } \\
\text { of DPN-diaphorase }\end{array}$} \\
\hline Nucleus ${ }^{\dagger}$ & $\begin{array}{c}\mu \mathrm{g} \text { Forma- } \\
\text { zan, } 0.0434 \mathrm{~mm}^{3} \\
\text { tissue }\end{array}$ & Nucleus $†$ & $\begin{array}{c}\mu \mathrm{g} \text { Forma- } \\
\text { an/0.0434 } \mathrm{mm}^{3} \\
\text { tissue }\end{array}$ \\
\hline \multicolumn{4}{|c|}{ Diencephalon (thalamus) } \\
\hline $\begin{array}{l}\text { Nucl. anterior (dorsalis) } \\
\text { Cases } 1 \& 3 \\
\text { Case } 2 \\
\text { Nucl. lateralis pars anterior } \\
\text { Nucl. lateralis pars dorsalis } \\
\text { Nucl. lateralis pars ventralis } \\
\text { Nucl. arcuatus } \\
\text { Nucl. dorsomedialis } \\
\text { Anterior midline nuclei } \\
\text { Centre median } \\
\text { Midline-nuclear group } \\
\text { (dorsal portion) }\end{array}$ & $\begin{array}{l}45: 4 \\
36 \pm 2 \\
34:-6 \\
42: 5 \\
31=7 \\
45: \vdots 4 \\
44: 5 \\
45 \pm 3 \\
32=4 \\
32=3\end{array}$ & $\begin{array}{l}\text { Midline-nuclear group } \\
\text { deep transition into hypothala- } \\
\text { mus } \\
\text { Nucl. posterior } \\
\text { Pulvinar } \\
\text { Nucl. geniculatus medialis } \\
\text { Nucl. geniculatus lateralis } \\
\text { Capsula interna } \\
\text { Tract. mammillo-thalamicus } \\
\text { Tractus opticus }\end{array}$ & $\begin{array}{l}29 \pm 4 \\
37 \pm 4 \\
39 \pm 4 \\
44 \pm 5 \\
52 \div 11 \\
19 \pm 3 \\
20 \div 2 \\
14 \div 1\end{array}$ \\
\hline \multicolumn{4}{|c|}{ Diencephalon (subthalamic centres) } \\
\hline $\begin{array}{l}\text { Tuber cinereum (medial) } \\
\text { Tuber cinereum (lateral) } \\
\text { Tuber cinereum (supraoptic) } \\
\text { Nucl. mammillaris medialis } \\
\text { Cases } 1 \text { \& } 3 \\
\text { Case } 2\end{array}$ & $\begin{array}{l}30 \div 6 \\
30 \div 4 \\
35 \pm 4 \\
56 \div 8 \\
38 \div 5\end{array}$ & $\begin{array}{l}\text { Optic radiation } \\
\text { Nucl. subthalamicus } \\
\text { Zona incerta } \\
\text { Peduncular zone of nucl. inter- } \\
\text { calatus (see Fig. 15) }\end{array}$ & $\begin{array}{l}15 \pm 2 \\
37 \div 3 \\
24 \pm 1 \\
20: 3\end{array}$ \\
\hline \multicolumn{4}{|c|}{ Basal telencephalic centres } \\
\hline $\begin{array}{l}\text { Nucl. caudatus (caput) } \\
\text { Putamen } \\
\text { Pallidum externum } \\
\text { Pallidum internum } \\
\text { Capula interna }\end{array}$ & $\begin{array}{l}38 \div 3 \\
41: 13 \\
31 \pm 5 \\
27: 5 \\
16: 3\end{array}$ & $\begin{array}{l}\text { Ansa lenticularis } \\
\text { Claustrum } \\
\text { Amygdala (ventral nuclei) } \\
\text { Amygdala (dorsal nuclei) }\end{array}$ & $\begin{array}{l}13 \pm 3 \\
25: 3 \\
21 \pm 2 \\
29: 2\end{array}$ \\
\hline \multicolumn{4}{|c|}{ Precentral motor cortex } \\
\hline $\begin{array}{l}\text { Laminac II-IV } \\
\text { Laminae V-VI }\end{array}$ & $\begin{array}{l}39 \pm 4 \\
33 \pm 4\end{array}$ & Substantia alba & $15 \pm 4$ \\
\hline \multicolumn{4}{|c|}{ Frontal pole } \\
\hline $\begin{array}{l}\text { Laminae II-IV } \\
\text { Laminae V-VI }\end{array}$ & $\begin{array}{r}46 \cdot 5 \text { 上 } 3 \\
40: \mathrm{t} 7\end{array}$ & Substantia alba & $16 \therefore 2$ \\
\hline \multicolumn{4}{|c|}{ Parietal cortex } \\
\hline $\begin{array}{l}\text { Laminae II-IV } \\
\text { Laminae V-VI }\end{array}$ & $\begin{array}{l}40 \div 4 \\
37 \pm 5\end{array}$ & $\begin{array}{l}\text { Substantia alba } \\
\text { Insular cortex (general) }\end{array}$ & $\begin{array}{l}16 \pm 1 \\
34 \pm 3\end{array}$ \\
\hline \multicolumn{4}{|c|}{ Occipital cortex } \\
\hline $\begin{array}{l}\text { Laminae II-III } \\
\text { Laminae IV }\end{array}$ & $\begin{array}{l}44 \pm 6 \\
53 \pm 10\end{array}$ & $\begin{array}{l}\text { Laminae V.-VI } \\
\text { Substantia alba }\end{array}$ & $\begin{array}{l}39 \doteq 7 \\
16 \pm 2\end{array}$ \\
\hline
\end{tabular}

† Anatomical names according to OLszewsKI and BaXTer (1954). 
TABLE 1 (cont' $d$ )

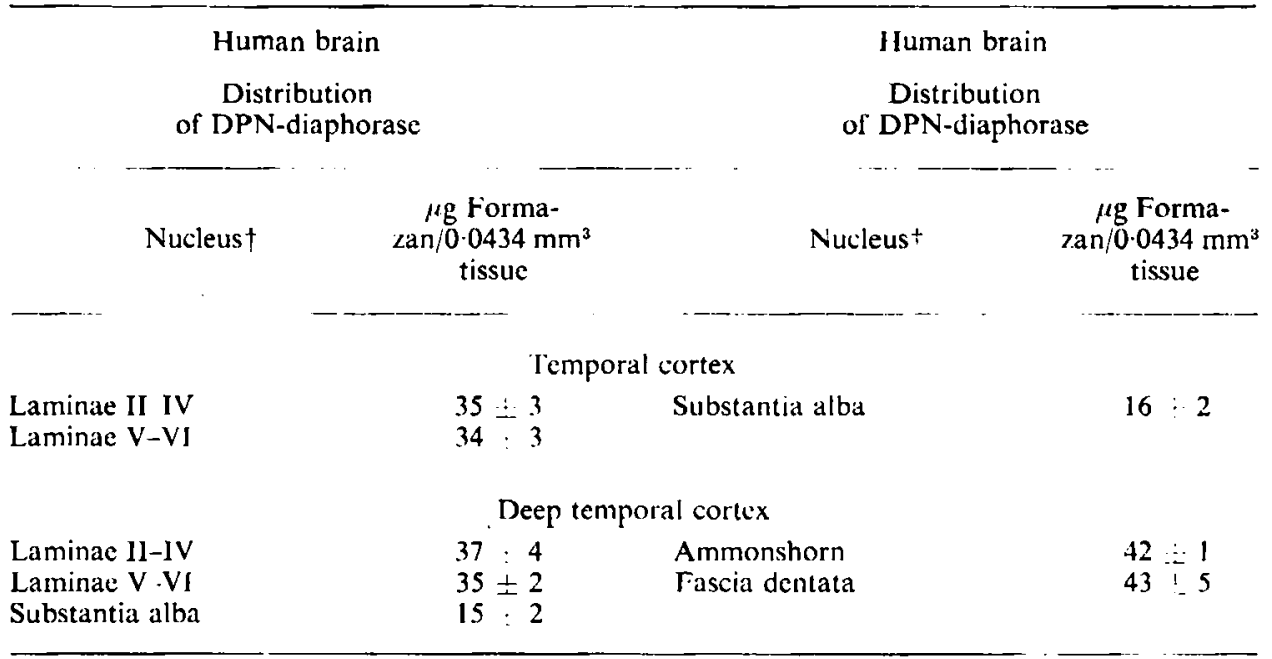

$†$ Anatomical names according to Olszewskı and BAxter (1954).

Correlation coefficients for the data in Table 1.

A. Correlation of DPN-diaphorase (man) and succinic dehydrogenase (cat): $0 \cdot 863$.

B. Corrclation of DPN-diaphorase (man) and capillarization (cat): 0.932 .

C. Correlation of succinic dehydrogenase (cat) and capillarization (cat): 0.879 .

of nuclei. Some of the measurements from Table 1 are repeated in Table 2 to facilitate comparison of general gradations and cytological pattern.

A series of photomicrographs (Figs. 1-19) shows the typical patterns of enzyme distribution. Since most of the information concerning them is included in Tables 1 and 2 , the following text is limited to certain general conclusions.

\section{A comparison of densitometric and spectrophotometric formazan measurements}

The data from the cat brain studies have been included in this paper for comparison of the enzyme patterns in the two species as well as for comparison of the technical reliability of the densitometric and spectrophotometric measurements. The almost identical data obtained by tissue densitometry and by the spectrophotometric measurement of extracted formazan showed that both methods, handled with necessary caution, were reliable and exact for the demonstration of enzyme patterns in the brain. Microscopic densitometry permitted one to focus a small nucleus more closely. The spectrophotometric data provided a general average of the region, sometimes including adjacent tissue with a weaker reaction. Slightly higher densitometric data were marked by an asterisk wherever we felt that the spectrophotometric data included some adjacent tissue with a weaker reaction. The densitometric readings were slightly lower in comparison with the spectrophotometric data in all regions with very weak reaction, particularly in white matter.*

* Data ubtained since the submittance of this paper (using both assays and histochemical measurements) indicated that the proportion of gray and white matter was truly greater for succinic dehydrogenase than for DPN-diaphorase. 
There has been some recent discussion as to the specificity of various tetrazolium salts. The densitometric data on the cat refer to sections stained with Nitro BT while the spectrophotometric data refer to INT. The nearly identical results do not indicate any significant differences among these tetrazolium salts.

\section{Comparison of cat and human medulla oblongata}

An atlas of the distribution of four oxidative enzymes (succinic dehydrogenase, cytochrome oxidase, DPN- and TPN-diaphorase) in the cat brain stem has been published (FrIEDE, 1961c). The densitometric measurements of succinic dehydrogenase reported in this atlas are included in Table 1. Comparing the pattern of succinic dehydrogenase in the cat brain with that of DPN-diaphorase in human brain, one was struck by their similarity. The general gradations among nuclei were identical for both species; even detailed gradations within certain nuclei were alike. For example, the portions of the reticular formation which project to the cercbellum (nucl. reticularis paramedianus, nucl. reticularis lateralis, and nucl. reticularis tegmenti of Bechterew) showed markedly stronger enzymic activity than that of the rest of the reticular formation (compare Figs. 2, 3 and 9). Furthermore, the detailed gradations of enzymic activity in the central grey substance were identical in both species: Enzymic activity decreased from the pons to the caudal part of the aqueduct. At the level of the inferior colliculus there was stronger enzymic activity in the dorsal part than in the ventral part of the central gray matter, the latter showing exceptionally weak activity. At the level of the supcrior colliculus, enzymic activity increased, being strongest in the dorsal-lateral portions. The measurements in the cat cervical cord and cerebellum did not match the human data. This is difficult to interpret without further investigation.

Measurements in the human brain were made only for DPN-diaphorase. Random sections were studied for succinic dehydrogenase and cytochrome oxidase. These enzymes showed the same distribution as DPN-diaphorase. Such observations and the data from the cat brain provide evidence that the patterns of several oxidative enzymes and of capillarization are identical, evidently indicating normal gradations of the oxidative metabolism among nuclei.

\section{Comparison of the diencephalon of man and guinea pig}

The enzyme pattern of the medulla oblongata did not seem to change among the species studied. However, in the thalamus there were marked differences between man and guinea pig. The present mapping of DPN-diaphorase and random material on succinic dehydrogenase and cytochrome oxidase in man was compared with the distribution of succinic dehydrogenase (FRIEIE, 1961 $a$ ) and DPN-diaphorase in the guinea pig.

Gradations among thalamic nuclei were much less accentuated in man than in the guinea pig, where the individual nuclei formed quite contrasting patterns. However, considerable gradations of enzymic activity were observed within certain human thalamic nuclei, such as the ventral and lateral nuclei and the pulvinar. These were characterized by irregular bizarre patches of strong enzymic activity. These patterns were too diversified to permit one to distinguish the typical findings from individual variations. Two areas showing distinct species differences, presumably phylogenetic, 


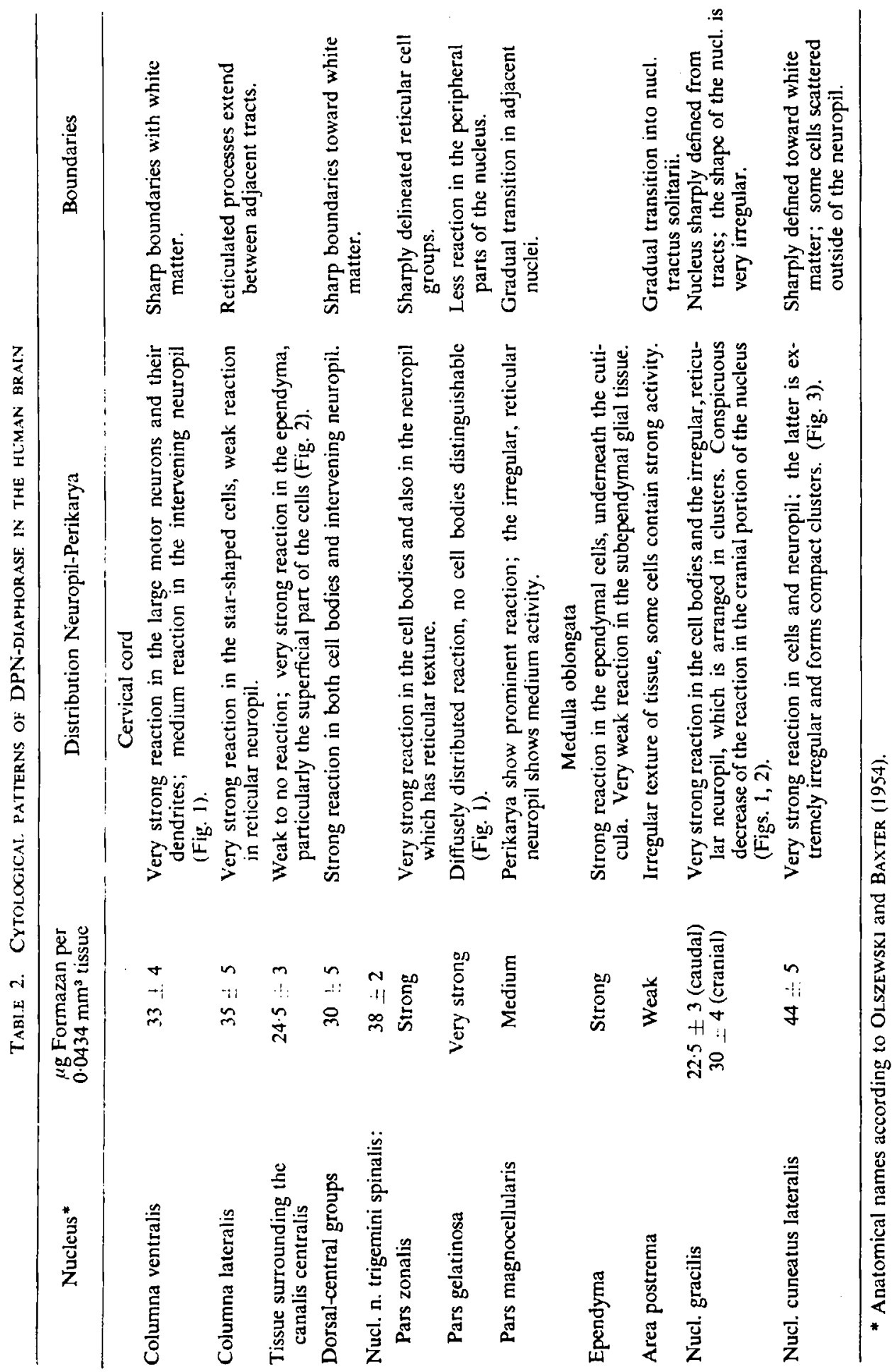




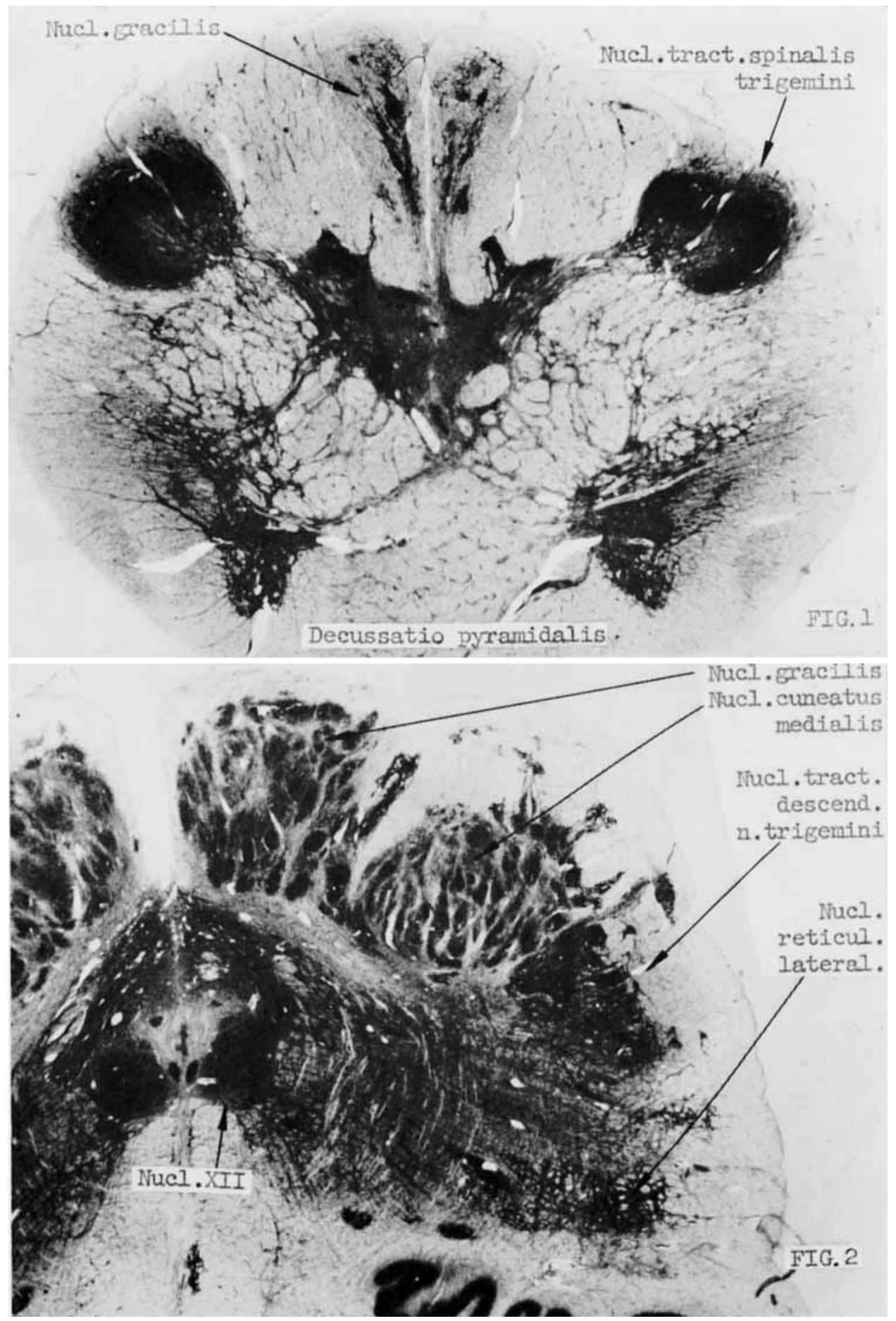

FIG. 1.- Cervical cord approximately at the level of C.1.

FiG. 2.-Medulla oblongata caudal to the fourth ventricle (the ventral portion of the section was deleted because of its identity with Fig. 3).

Consult Table 2 for a detailed description of the nuclei labelled. Both figures demonstrate DPN-diaphorase activity in $30 \mu$ sections. 


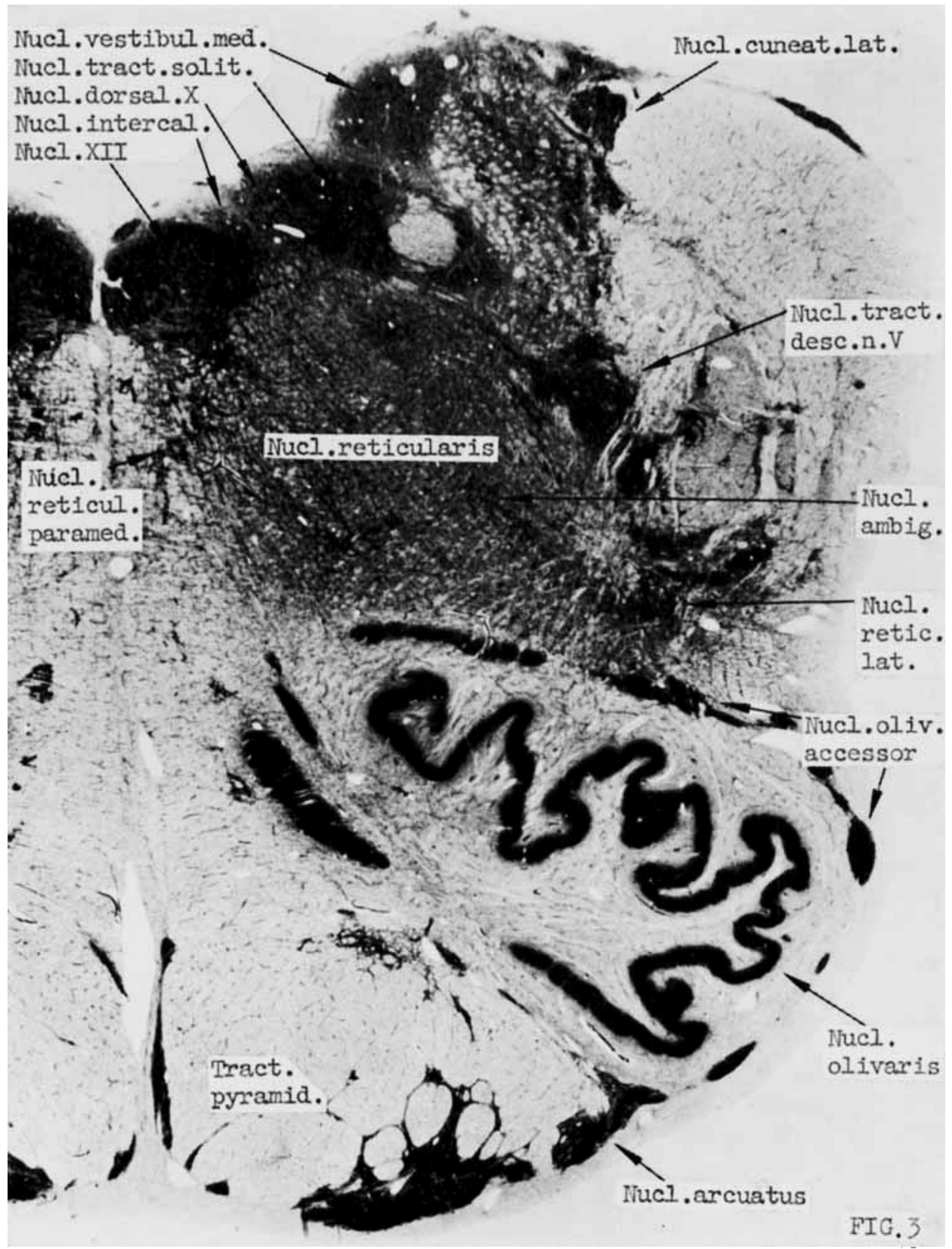

Fig. 3.- Medulla oblongata level of the hypoglossal nucleus. Consult Table 2 for a detailed description of the nuclei labelled. The figure demonstrates DPN-diaphorase activity in $30 \mu$ sections 


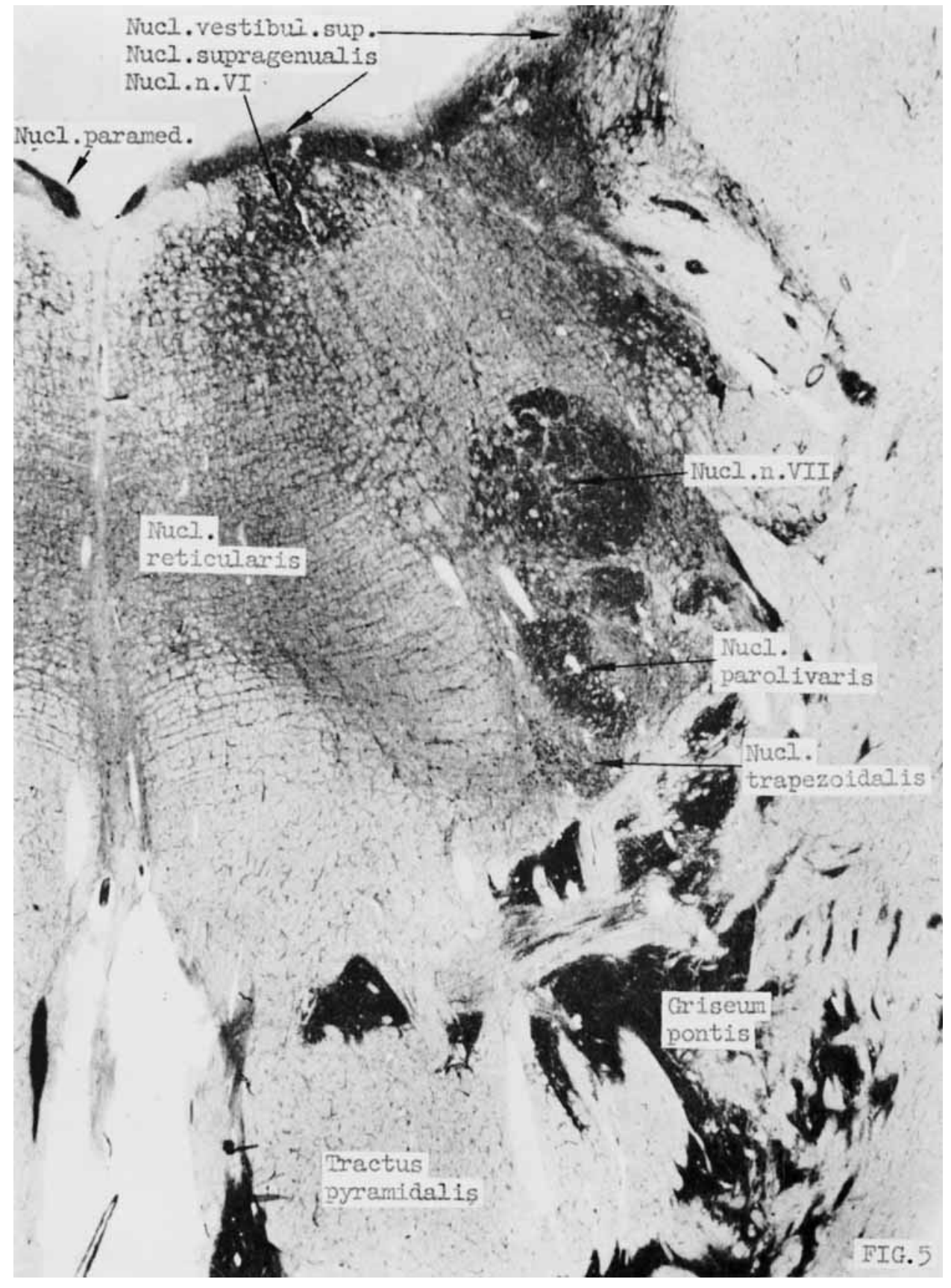

FIG. 4.-Medulla oblongata; level of the vestibular nuclei. Consult Table 2 for a detailed description of the nuclei labelled. The figure demonstrates DPN-diaphorase activity in $30 \mu$ section. 


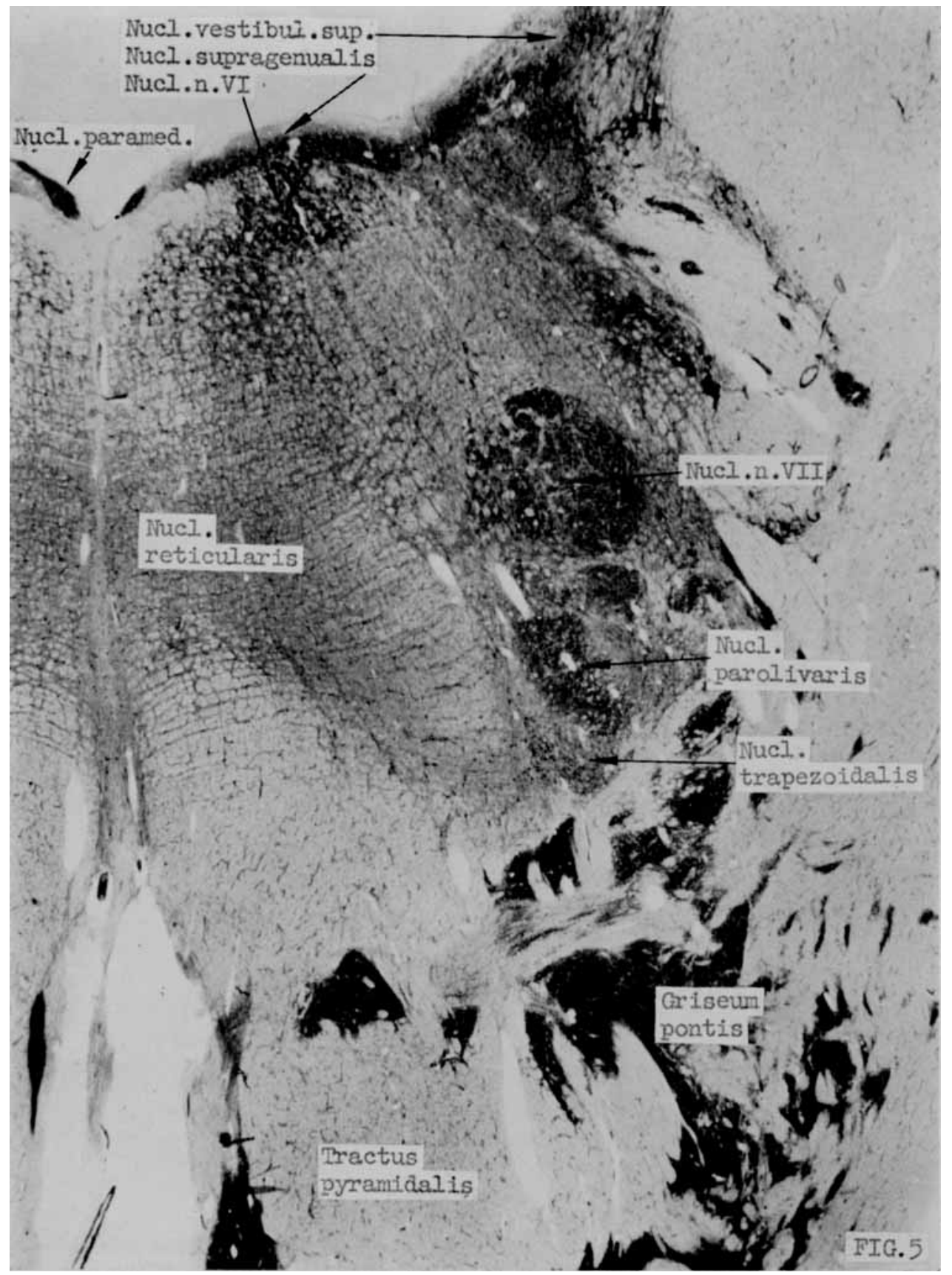

Fic. 5. Pons, caudal portion. Consult Table 2 for a detailed description of the nuclei labelled. The figure demonstrates DPN-diaphorase activity in $30 \mu$ section. 


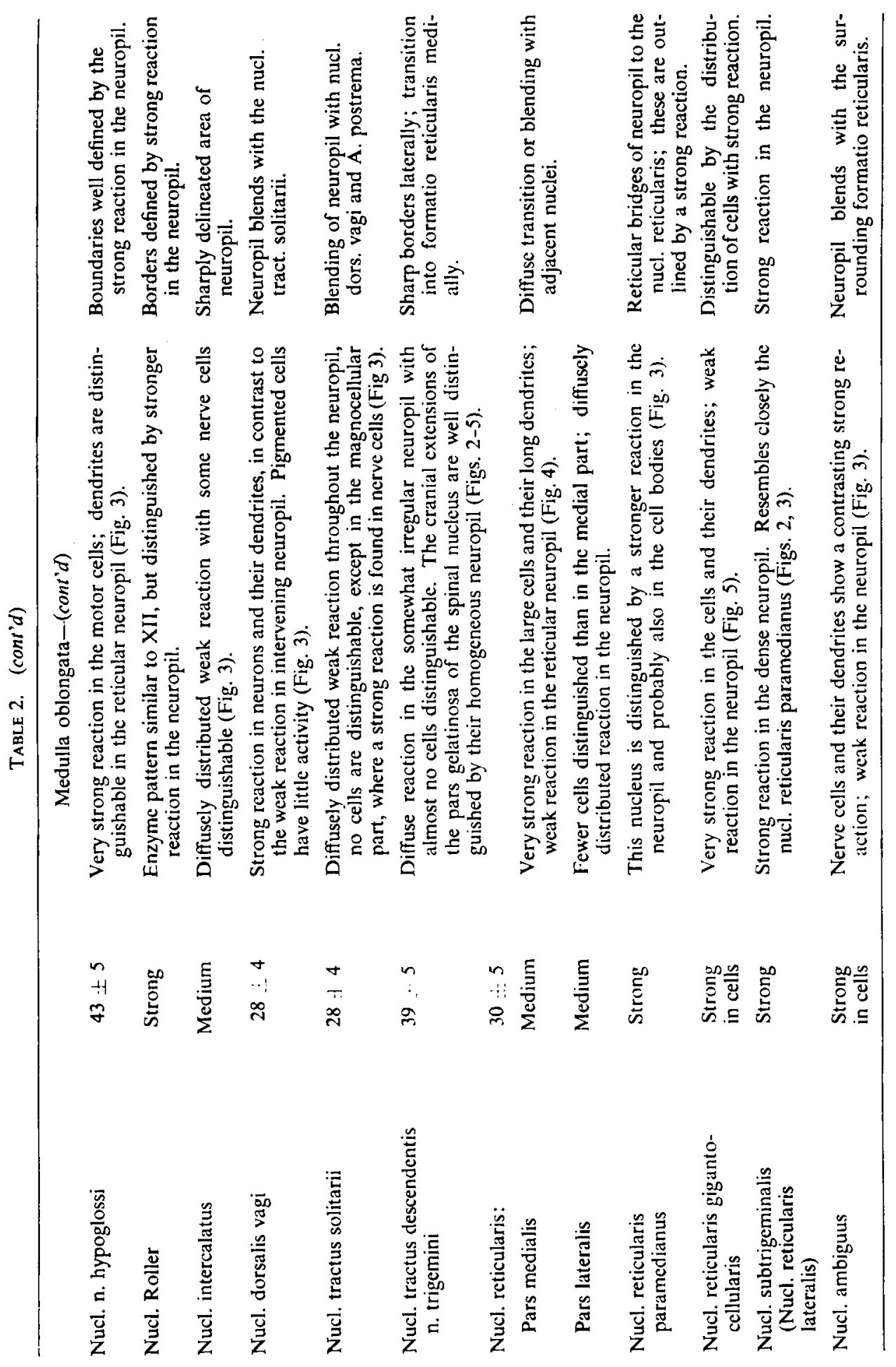




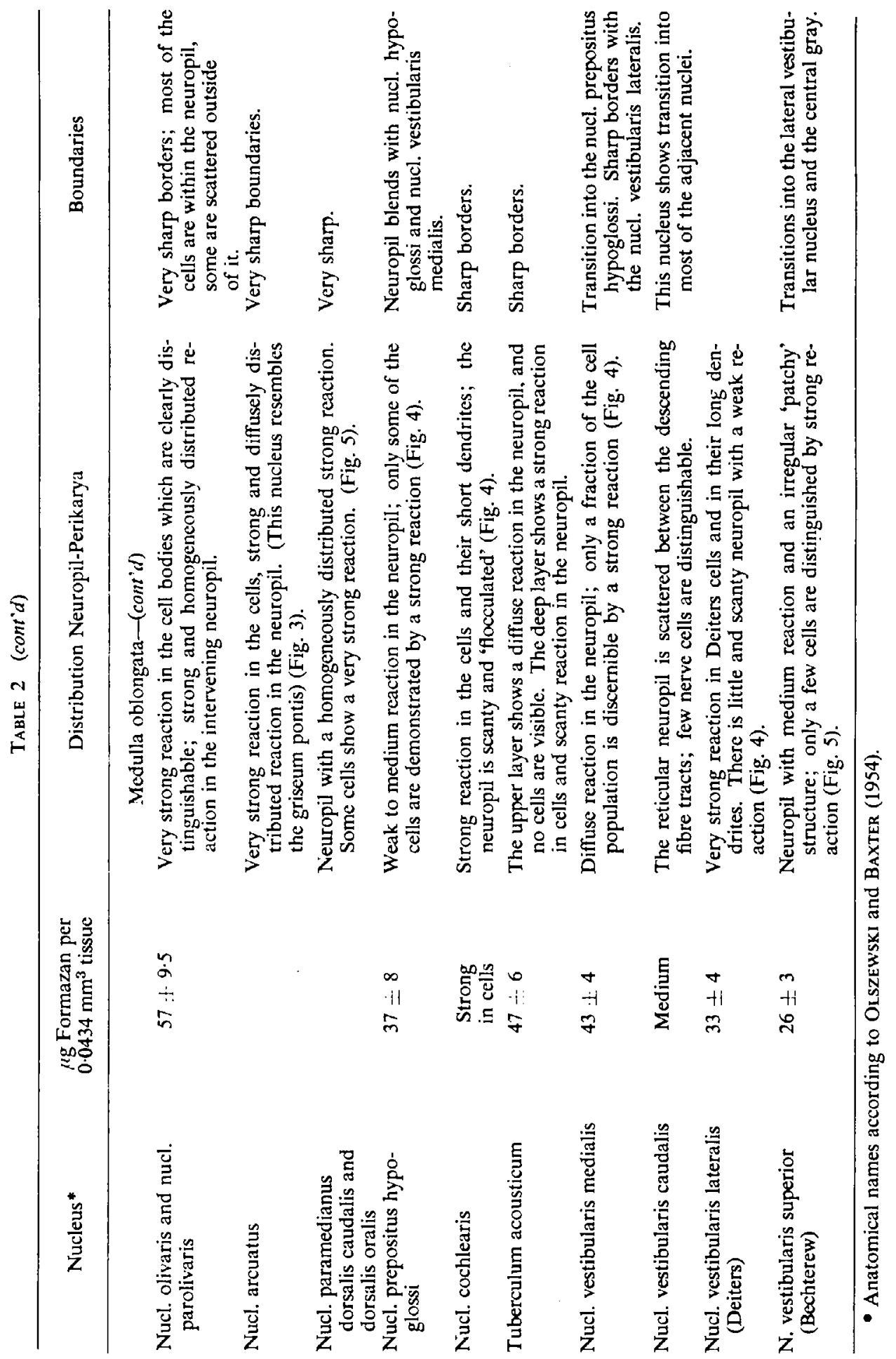


Oxidative enzymes in human brain

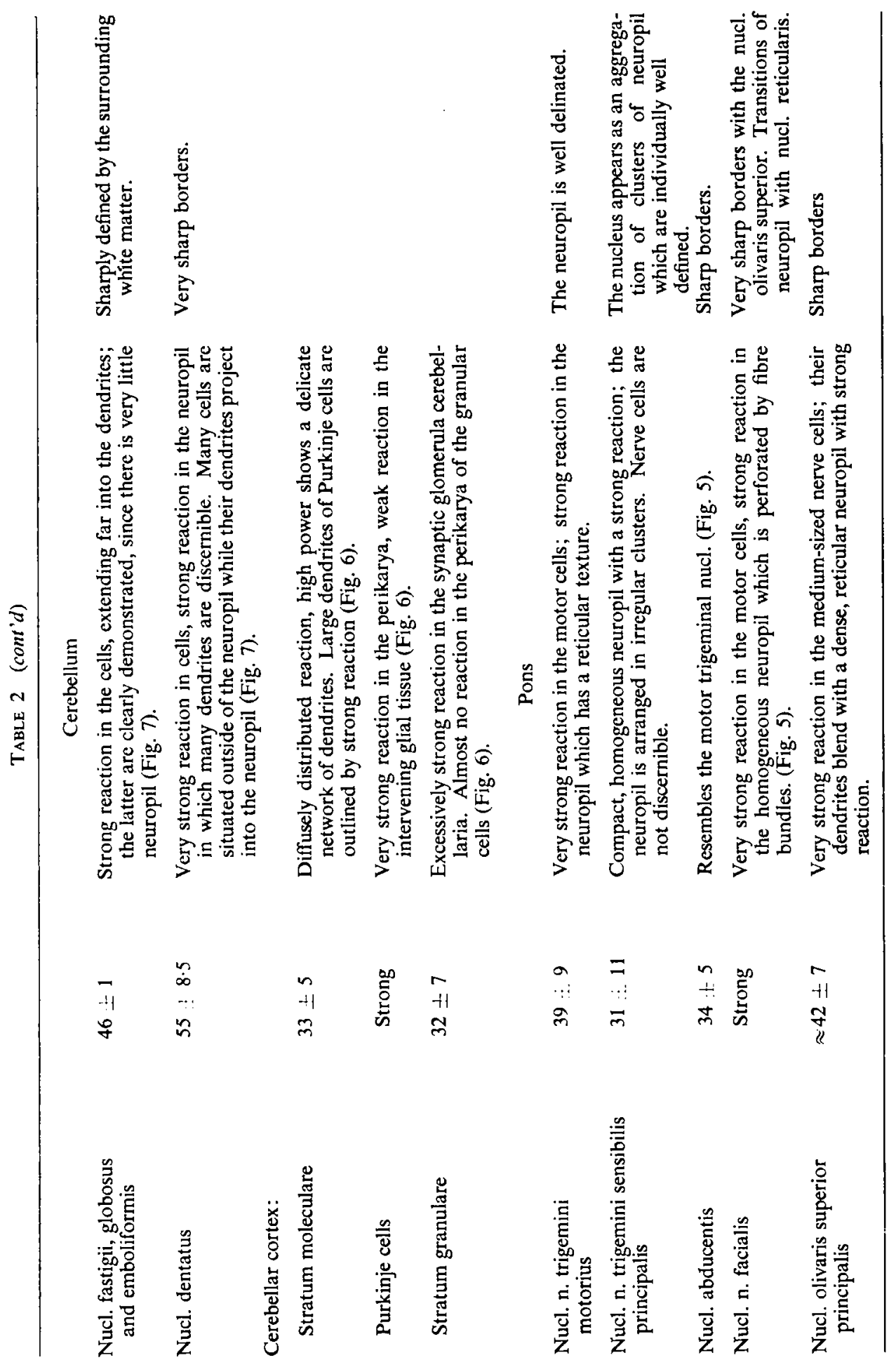




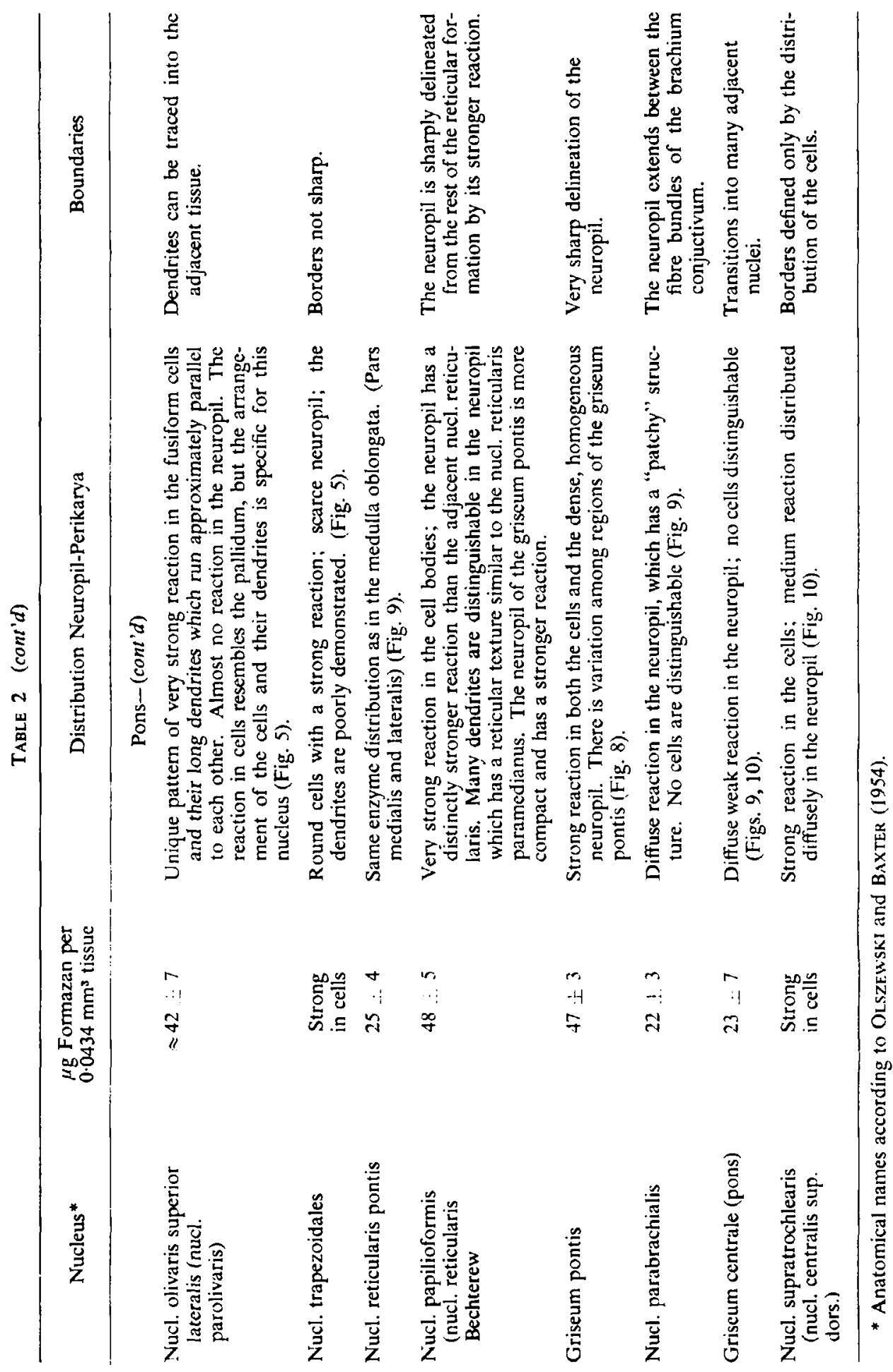




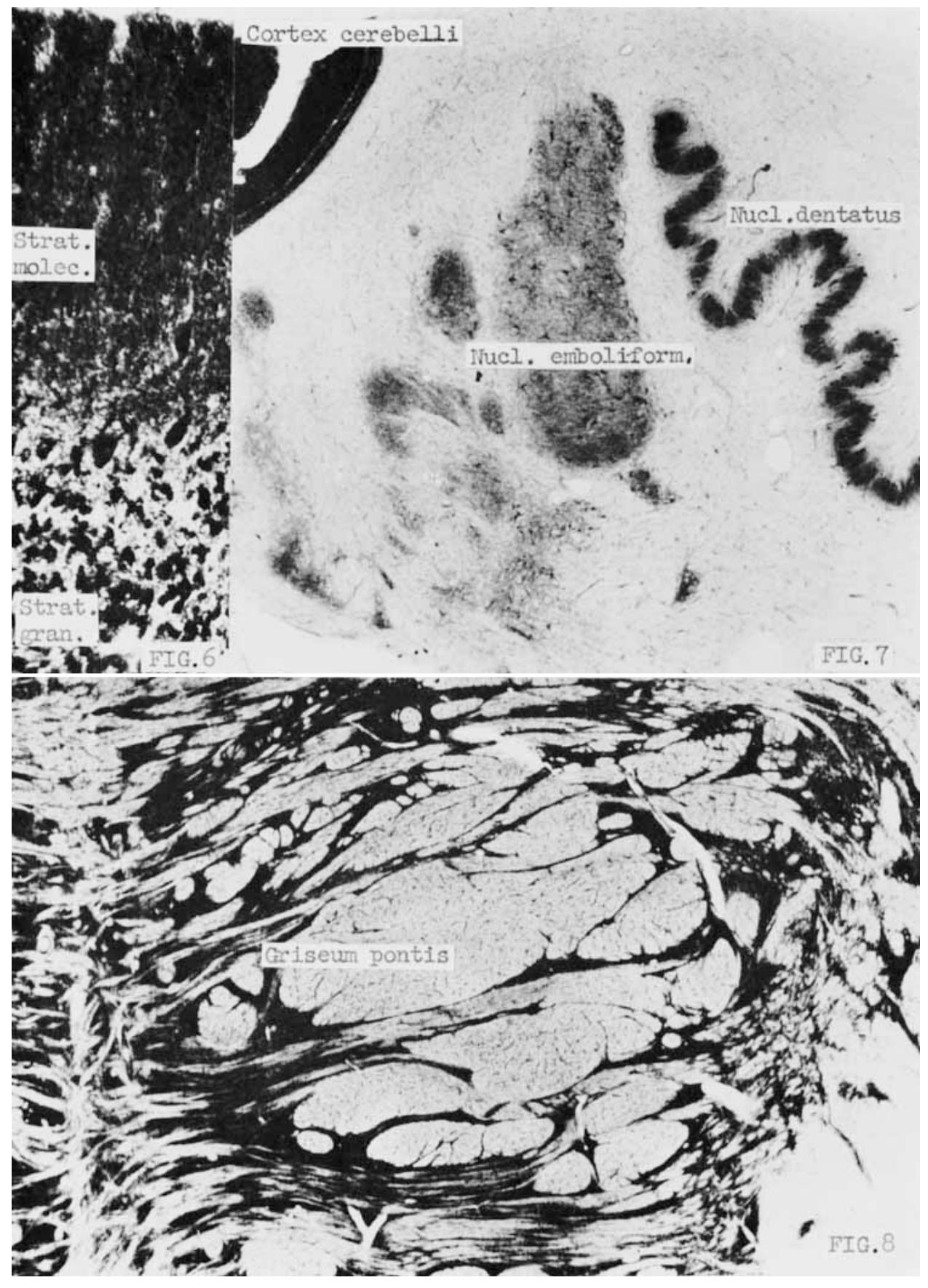

FiG. 6. High power enlargement of the cerebellar cortex (compare Fig. 7 for reference). Fig. 7.--Cerebcllar nuclei.

Fig. 8.-Pontine grey.

Consult Table 2 for a detailed description of the nuclei labelled. All figures demonstrate DPN-diaphorase activity in $30 \mu$ sections. 


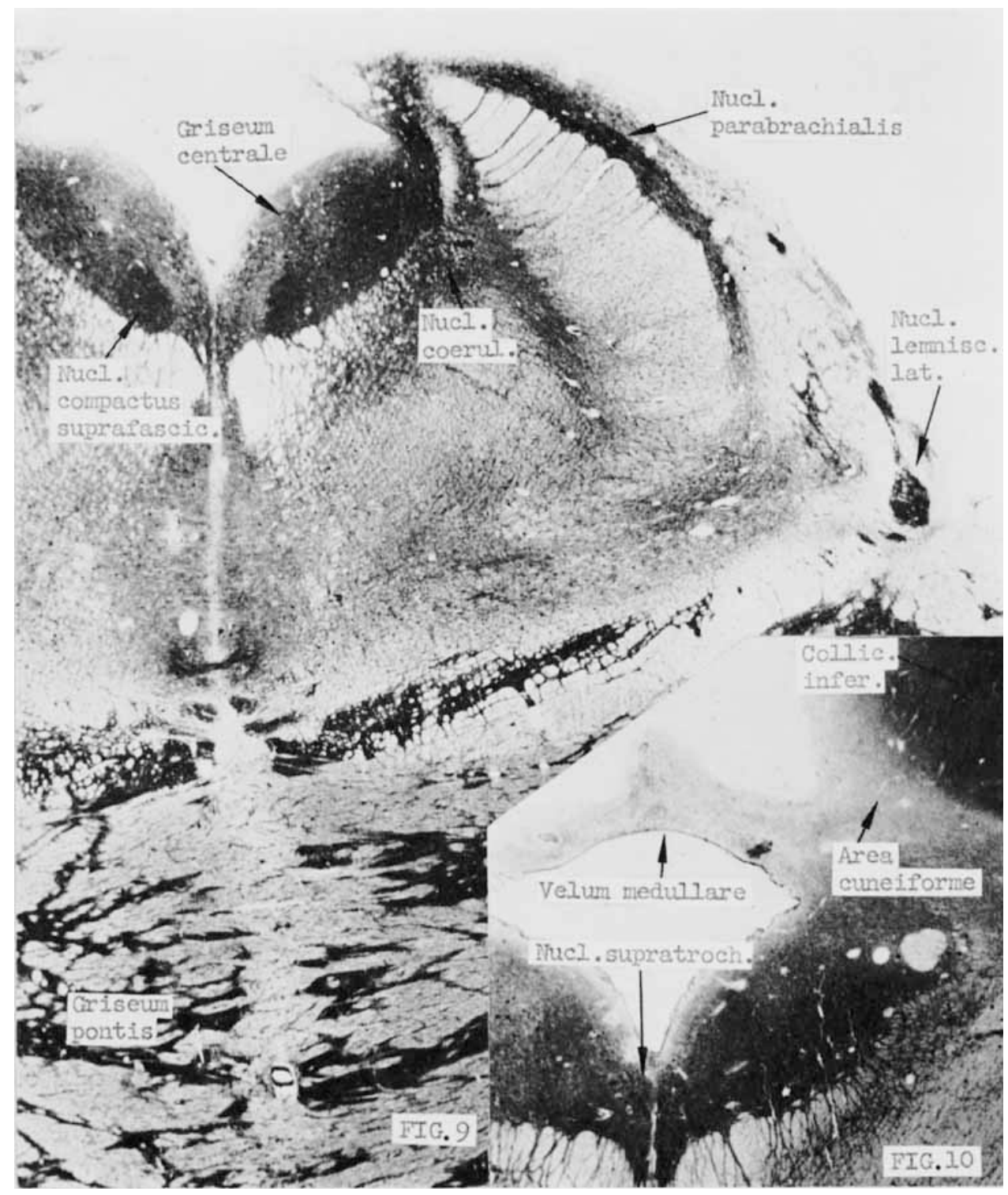

Fig. 9. Pons; level of the oral portion of the fourth ventricle.

Fig. 10.--Velum medullare anterius; level of the caudal orifice of the aqueduct. Consult Table 2 for a detailed description of the nuclei labelled. Both figures demonstrate DPN-diaphorase activity in $30 \mu$ sections. 


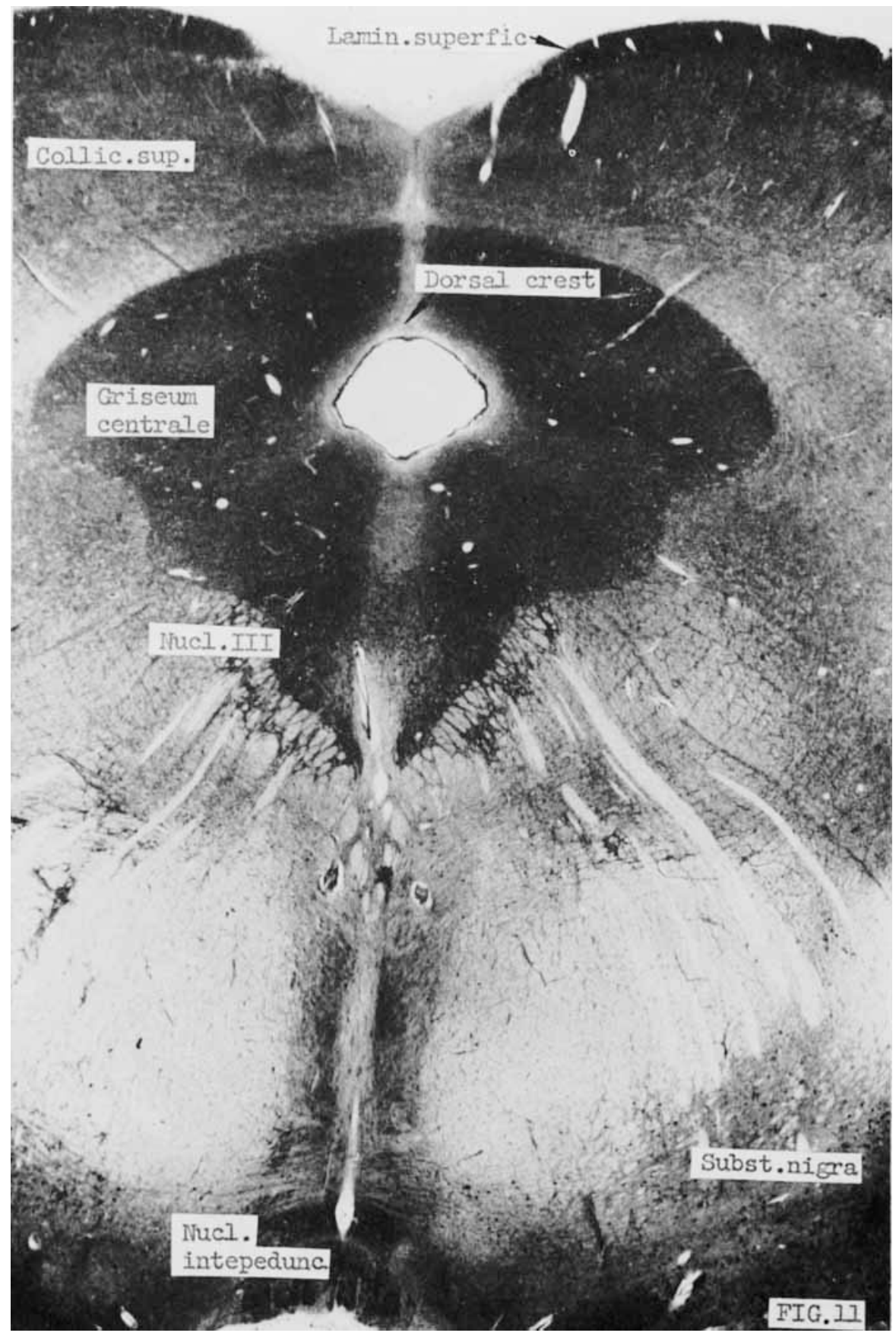

Fig. 11.- Midbrain; level of the upper colliculi. Consult Table 2 for a detailed description of the nuclei labelled. The figure demonstrates DPN-diaphorase activity in $30 \%$ section. 


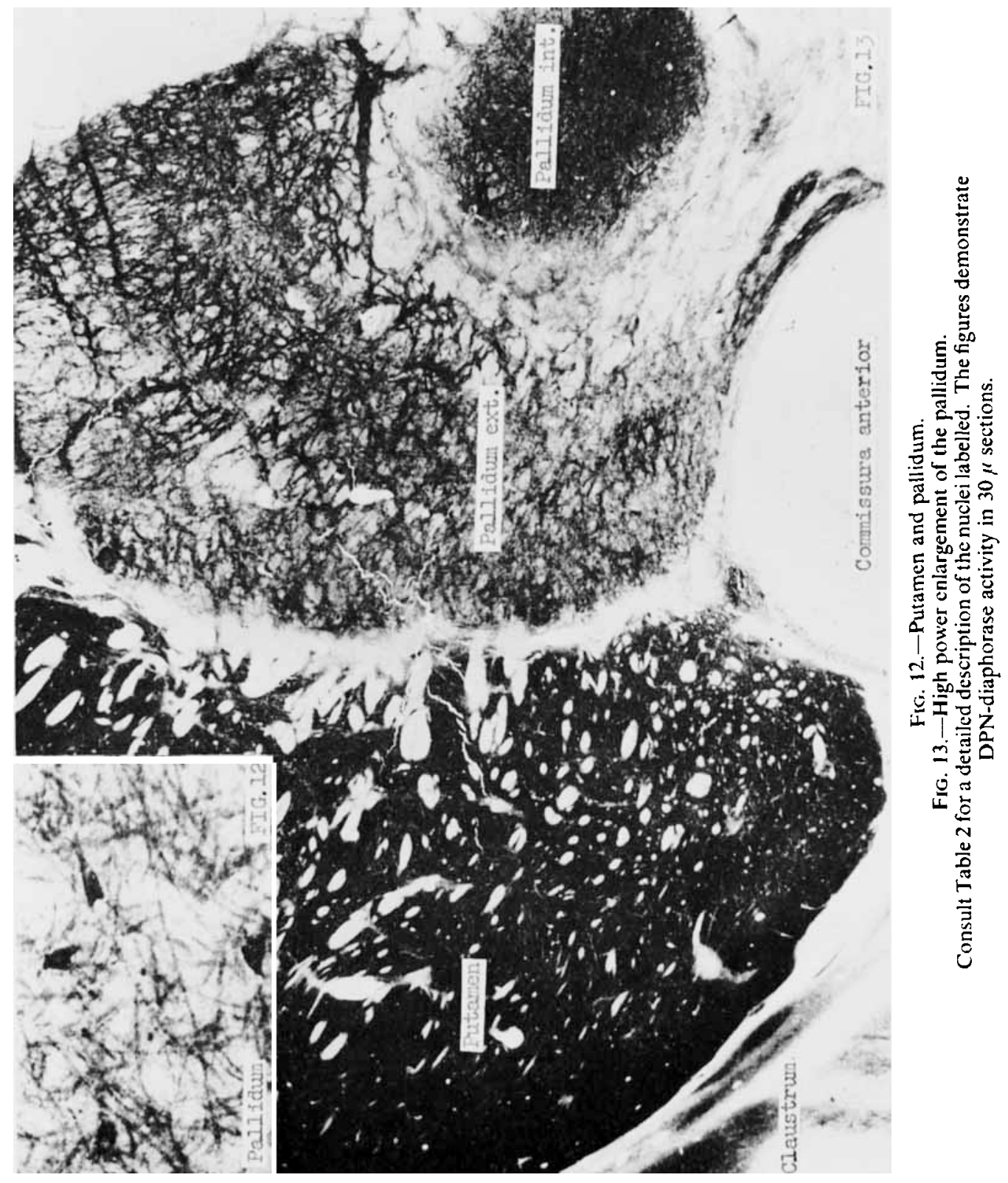




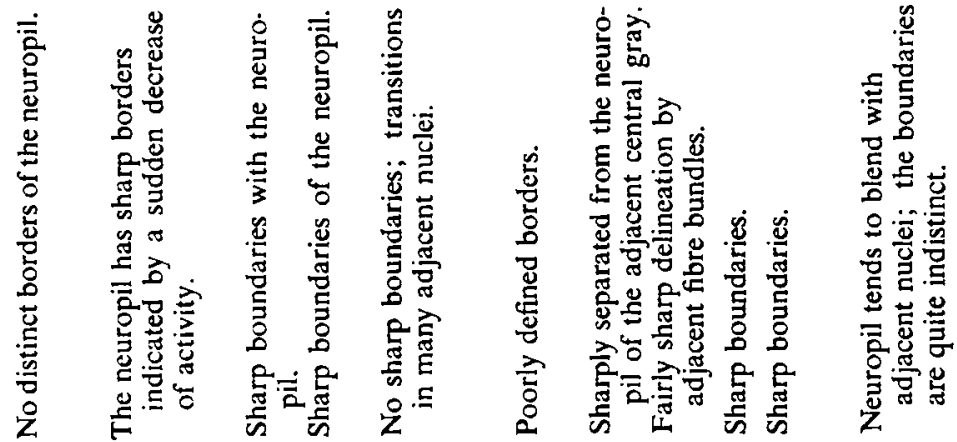

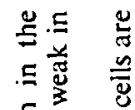

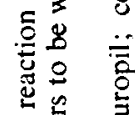 \\ 范总 \\ 尊密

言范

-1
+

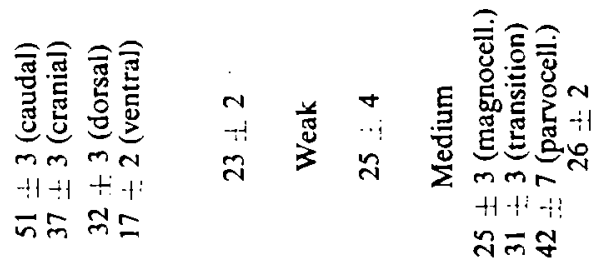

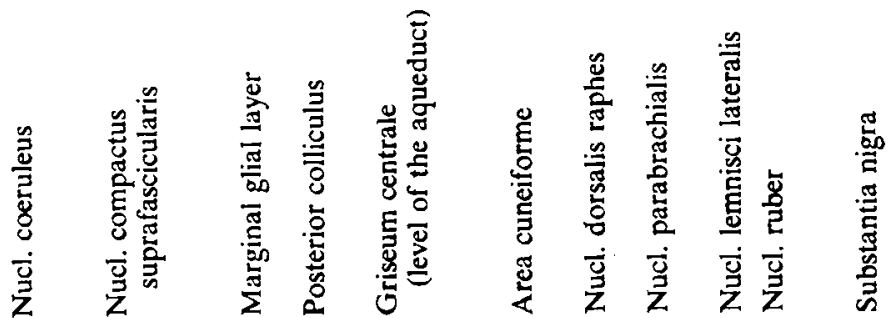




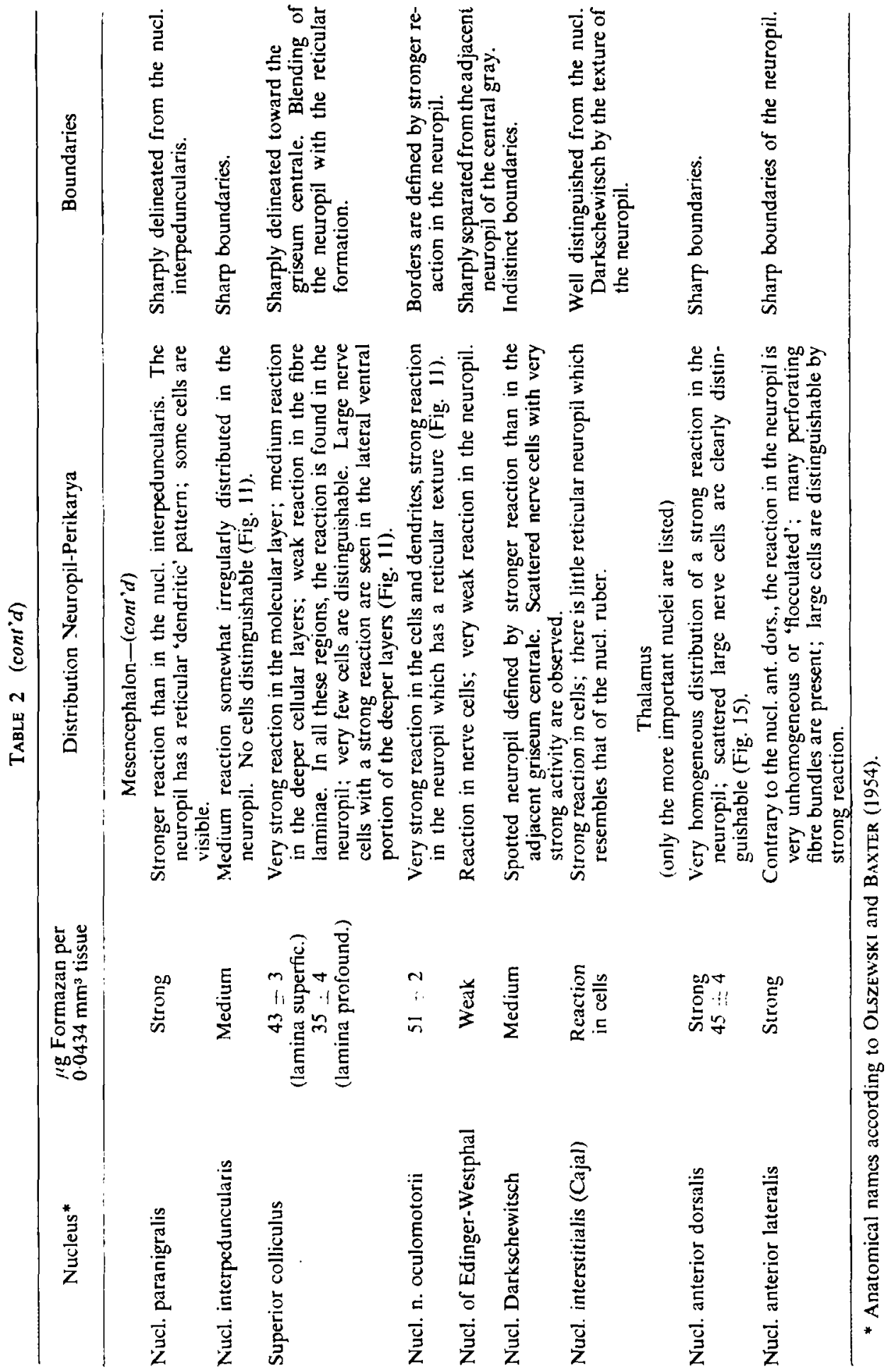




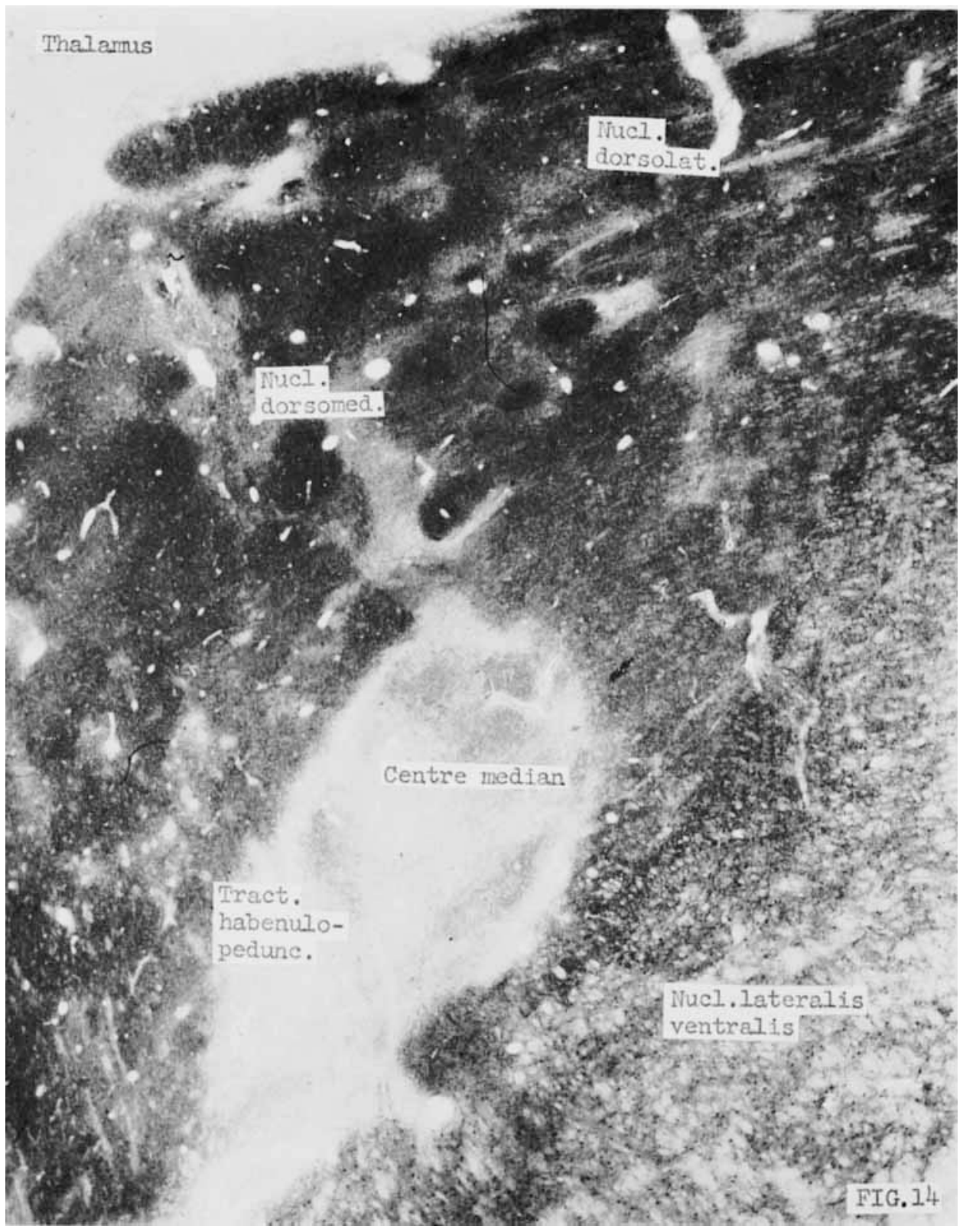

Fig. 14.- Thalamus, middle portion. Consult Table 2 for a detailed description of the nuclei labelled. The figure demonstrates DPN-diaphorase activity in $30 / \mu$ section. 


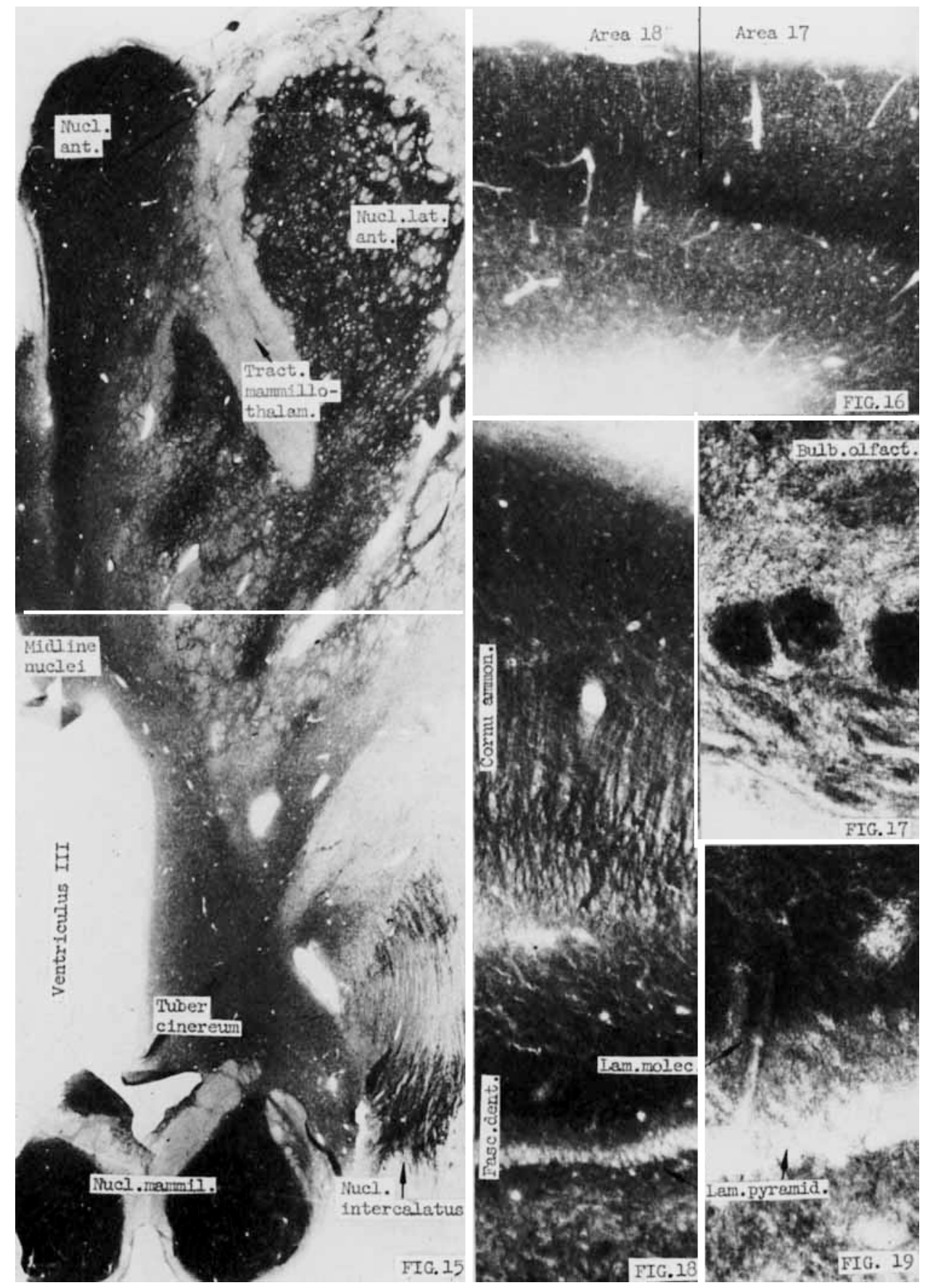

Fig. 15. --Thalamus and hypothalamus, anterior portion.

FIG. 16.-Cerebral cortex; border between area 17 and 18 .

FIci. 17.-High power enlargement of the olfactory bulb.

FIG. 18. -Survey of the layers of the cornu ammonis and the fascia dentata.

FIG. 19. High power enlargement of the fascia dentata.

Consult Table 2 for a detailed description of the nuclei labelled. All figures demonstrate DPN-diaphorase activity in $30 \mu$ sections. 


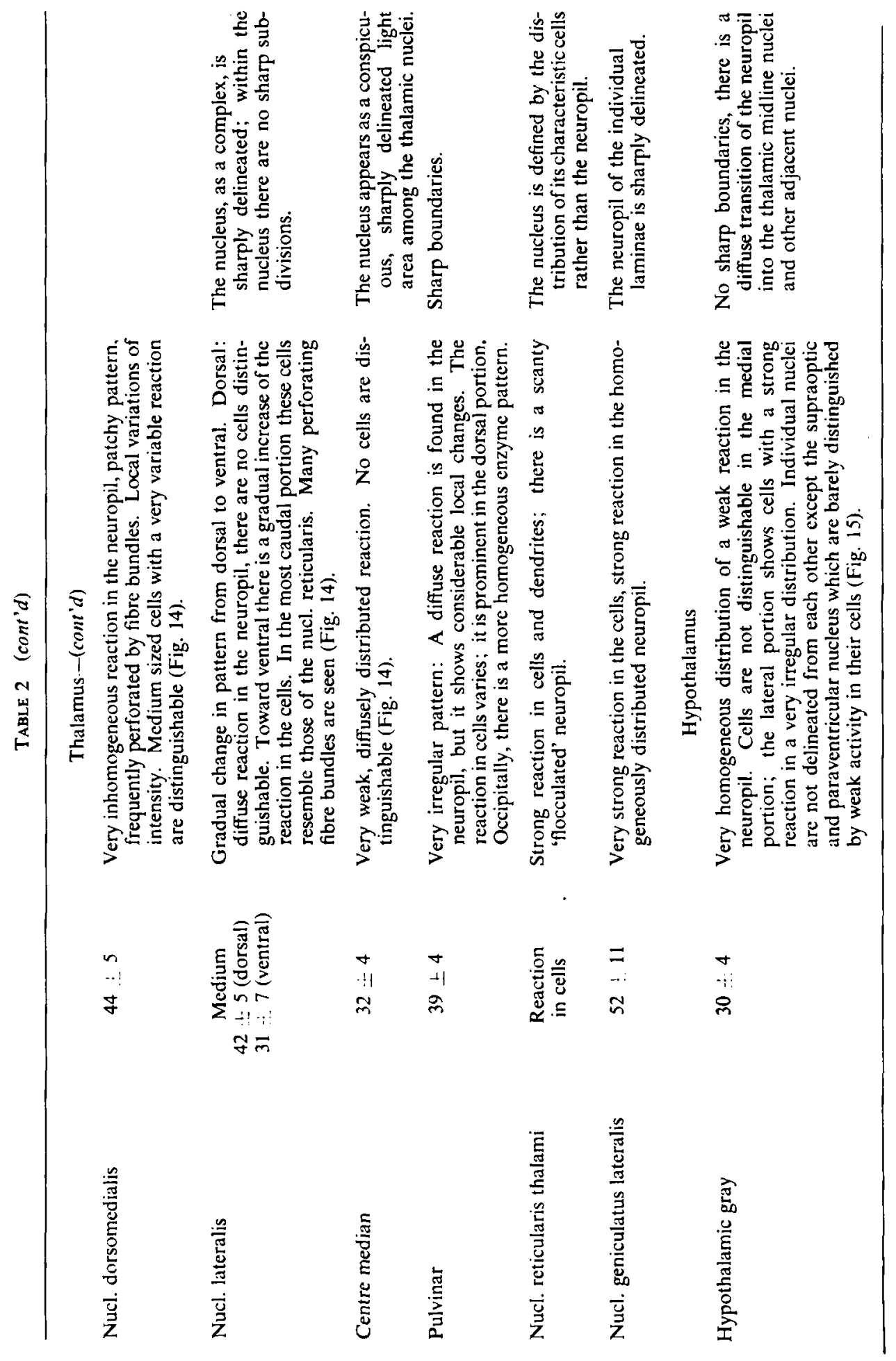




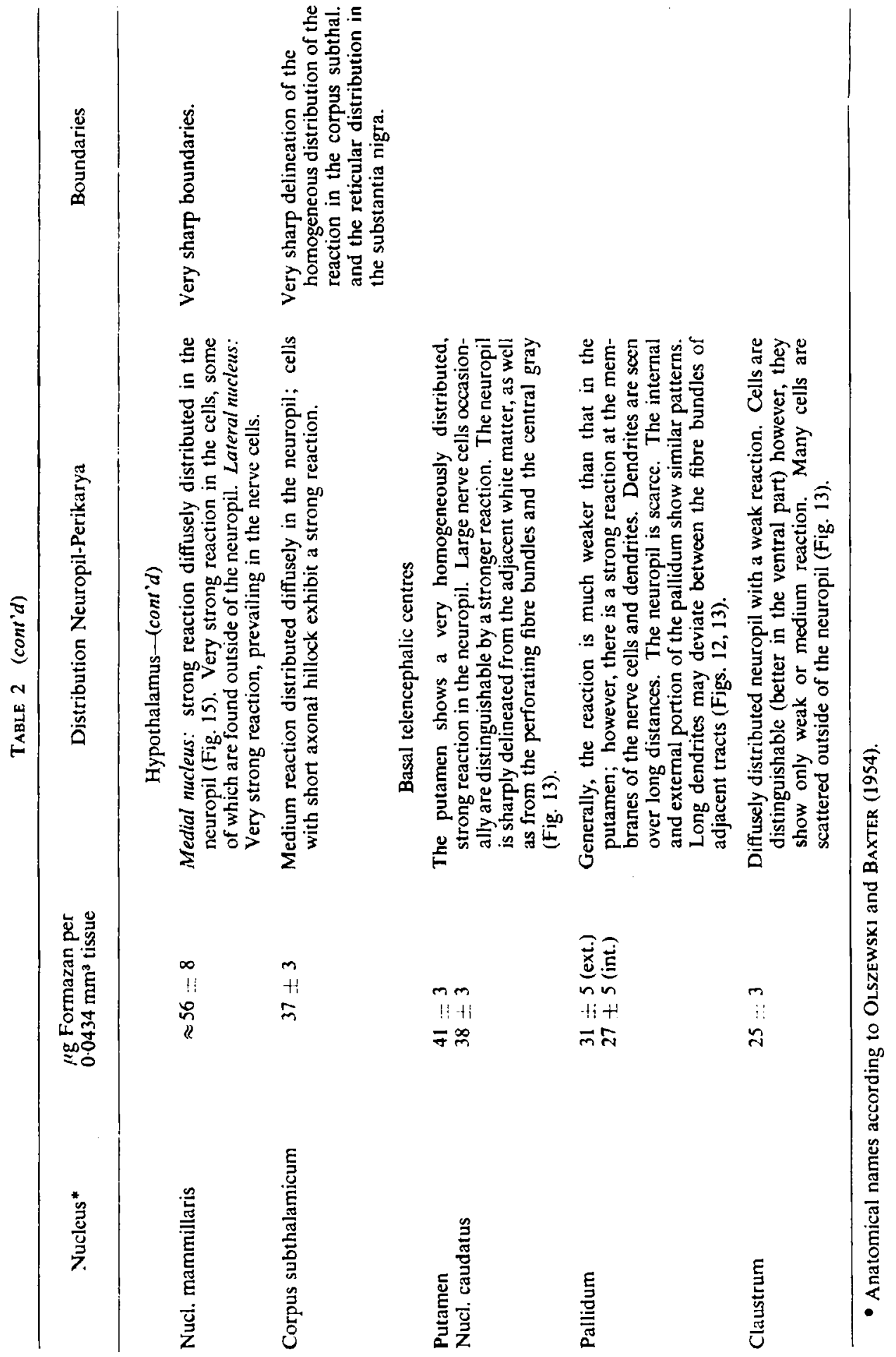




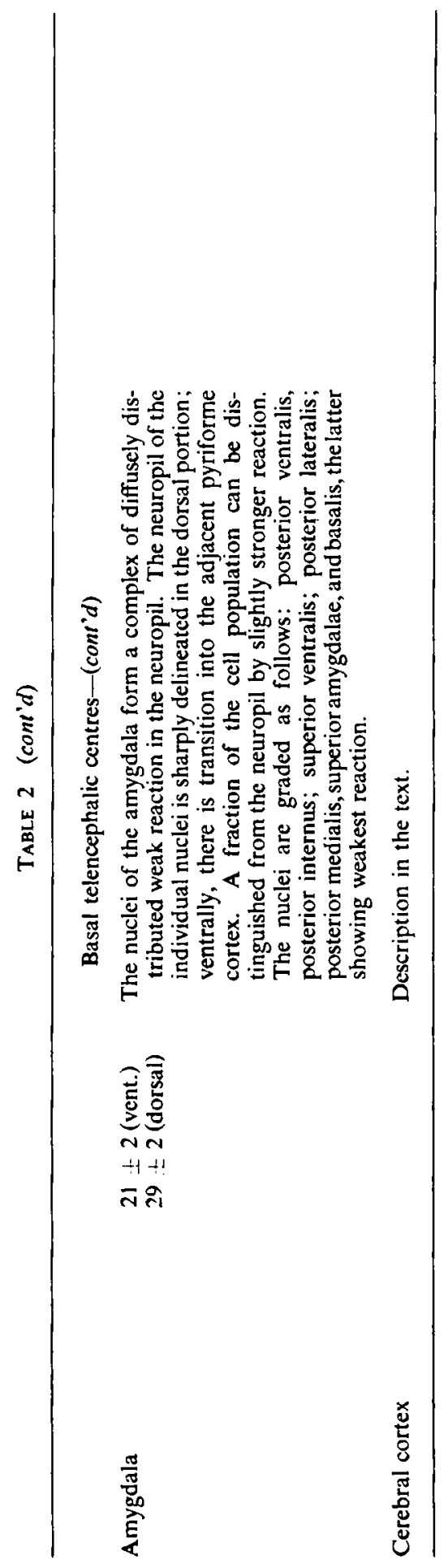


were the centre median and the dorso-medial nucleus. As the histochemical sections clearly demonstrated (Fig. 14), the human brain showed a well defined centre median with low enzyme activity appearing as a 'punched out' area; this pattern was not observed in the guinea pig. The human dorso-medial nucleus had relatively strong enzyme activity in contrast to the weak activity of the homologous region in the guinea pig. This was in accordance with the findings for the fronto-polar cortex which likewise had strong activity in man and weak activity in the guinea pig. The extra thalamic diencephalic centres had similar enzyme patterns in both species, such as the weak activity in the hypothalamus, or the contrasting differentiation of the corpus subthalamicum (strong reaction) from the substantia nigra (weak reaction).

These observations indicate a tendency of caudo-cranial differentiation of the chemo-architecture of the brain. The human thalamus resembled only general outlines of the guinea pig pattern, while the patterns in the medulla oblongata were alike.

Cerebral isocortex. The enzyme patterns in the areas of human isocortex were similar to each other in principle but showed minor variations in the individual areas. The upper four layers showed diffusely distributed enzyme activity in the neuropil, in which only a few perikarya of pyramidal cells were distinguishable by stronger enzymic activity. There was an increase of enzyme activity from the first, or molecular, layer toward the second and third layers. The fifth and sixth layers showed a decrease of enzyme activity in the neuropil; many, but not all of the pyramidal cells exhibited strong activity in their perikarya and the proximal dendrites; there were considerable gradations of activity among individual pyramidal cells. This general pattern varied among the cortical areas as to the thickness of the layers, the number of perikarya with strong enzymic activity and a finer gradient of activity in the neuropil. However, the present large cortical material revealed such an abundance of minor differences among specimens and regions that it was difficult to distinguish the typical fcatures of an area from individual variations. The visual cortex (Area 17) and the postcentral region were characterized by a thin lamina of very strong enzyme activity in the fourth layer; this lamina terminated sharply at the borders of the optic arca (Fig. 16), while it showed smoother transitions in the postcentral region. Spectrophotometric measurements of formazan revealed the typical gradations among regions as found in the guinea pig cortex (FRICDL, 1960); however, the differences among areas were less accentuated in man than in the guinea pig. For both species, gradations among cortical areas were characteristic in the IInd to IVth layers; the temporal cortex showed weakest enzyme activity, having less than the frontal and the parietal cortex, while highest activity was in the occipital and postcentral cortex. The strong enzymic activity in the fronto-polar region was in contrast to the findings of weak activity in the guinea pig.

The gradations of succinic dehydrogenase activity in the upper cortical layers of the guinea pig were paralleled by similar gradations among the thalamic nuclei which project to these regions. This correlation was not as clear-cut in the human brain, since gradations of enzymic activity were less accentuated both in the thalamus and the cortex. The high activity in the fronto-polar cortex was reflected by high activity in the dorso-medial thalamic nucleus, which projects to the fronto-polar cortex.

Allocortex. The pyramidal cells of the fascia dentata (lamina pyramidalis) showed little DPN-diaphorase activity, thus appearing as a light stripe (Figs. 18 and 19). Strong activity was found in the adjacent molecular layer (lamina molecularis) which 
was sharply divided into a deep sublamina with weaker activity and an upper sublamina with stronger activity (Fig. 19). The ammonshorn (Fig. 18) showed a band of diffuse enzymic activity in the neuropil and relatively little in the perikarya of the pyramidal cells, except those in Sommer's sector, which showed some activity.

The olfactory bulb (Fig. 17) showed very strong activity in the synaptic glomerula olfactoria, and somewhat weaker activity in the outer plexiforme layer; little reaction was seen in perikarya. This pattern was identical with that in the guinea pig.

\section{DISCUSSION}

The present article is mainly of fact-finding nature; the volume and variety of data supplied renders it difficult to provide an adequate discussion. Several implications of chemo-architecture have been discussed in preceding articles on the guinea pig brain (FrIEDE, 1960; 1961a,c). The present discussion, therefore, is limited to a few general comments.

The purpose of knowledge of chemo-architecture is to help achieve the ultimate goal of understanding all metabolic phases in all regions of the brain. The dimensions of this task limit one either to complete mappings of the distribution of a few enzymes in the entire brain or to broader studies of a spectrum of enzymes in a selected region. Both approaches supplement each other and contribute toward the same goal.

The present data show almost identical patterns of the distribution of DPNdiaphorase, succinic dehydrogenase, and capillarization in the medulla oblongata even though the data were derived from different species and by different techniques. Random material and previous studies indicate a similar distribution of cytochrome oxidase and TPN-diaphorase. This substantiates the assumption that the patterns described demonstrate general gradations of tissue oxidation and energy metabolism, including particularly the citric acid cycle. With this baseline available, one can go on to compare in detail the patterns of enzymes involved in more specific metabolic phases such as the glucose-shunt, or the transmitter-substances.

Even at the present state of knowledge one can benefit from the application of these data to problems of neuropathology. A mapping of the deposition of lipofuscin in the nuclei in the aging human brain showed its extent to be proportional to the normal regional gradations of oxidative enzymic activity (FRIEDE, 1961d). This was considered as an indication that the deposition of lipofuscin, or "wear-and-tear pigment', was proportional to the regional 'wear and tear', that is, the intensity of the oxidative energy metabolism.

\section{SUMMARY}

This article provides a detailed mapping of the distribution of DPN-diaphorase in the human brain with histochemical enzyme techniques. Measurements of the gradations of the histochemical reactions were made by spectrophotometric measurement of the formazan formed. The mapping includes measurements in about 135 regions, a description of the cytological enzyme patterns, and 19 photomicrographs. Comparison with previous data from the cat brain reveals a striking similarity between the distribution of DPN-diaphorase in the human medulla oblongata and of succinic dehydrogenase and capillarization in the cat. The enzyme patterns described evidently reflect general gradations of oxidative energy metabolism.

A tendency towards caudo-cranial differentiation of the chemical architecture of the brain is noted, thalamus and cerebral cortex being the most variable regions. 


\section{REFERENCES}

Burstone M. S. (1958) J. Histochem. Cytochem. 7, 112.

Farbir E., Sternberg W. H. and Dunlap C. E. (1956) J. Histochem. Cytochem. 4, 254.

FRIEDE R. L. (1960) J. Neurochem. 5, 156.

FrIede R. L. (1961a) J. Neurochem. 6, 190.

FRIEDE R. L. (1961b) J. Neurochem. 8, 17.

FRIEDE R. L. (1961c) Histochemical Atlas of Tissue Oxidation in the Brain Stem of the Cat. Karger, New York.

Friede R. L. (1961d) Proceedings IVth Internat. Congr. Neuropath. Thieme, 1962.

Nachlass M. M., Tsou K. C., Souza E., Cheng C. S. and Seligman A. M. (1957) J. Histochem. Cytochem. 5, 420.

OIsZEwSKI J. and BAXTER D. (1954) Cytoarchitecture of the Human Brain Stem. J. P. Lippincott, Philadelphia.

Scarpelli D. G., Hess R. and Pearse A. G. E. (1958) J. Histochem. Cytochem. 6, 369.

Shelton E. and RiCE M. E. (1957) J. nat. Cancer Inst, 18, 117. 